Article

\title{
Applying Distributed Manufacturing to Product-Service System Design: A Set of Near-Future Scenarios and a Design Tool
}

\author{
Aine Petrulaityte *, Fabrizio Ceschin, Eujin Pei and David Harrison \\ Department of Design, Brunel University London, College of Engineering, Design and Physical Sciences, \\ Uxbridge UB8 3PH, UK; fabrizio.ceschin@brunel.ac.uk (F.C.); eujin.pei@brunel.ac.uk (E.P.); \\ david.harrison@brunel.ac.uk (D.H.) \\ * Correspondence: aine.petrulaityte@brunel.ac.uk
}

Received: 28 April 2020; Accepted: 11 June 2020; Published: 16 June 2020

\begin{abstract}
Product-Service Systems (PSS), if properly designed and implemented, represent a promising approach to sustainability. However, there is a number of organisational, cultural and regulatory barriers that hinder the widespread PSS implementation. In this paper, the authors investigated Distributed Manufacturing (DM) as a promising production model which can be applied to PSS to address some of its implementation barriers and improve its sustainability. To that end, existing PSS implementation barriers were collected and coupled with systematically analysed favourable DM features to describe a set of PSS+DM near-future scenarios, addressing the complete PSS lifecycle. Scenarios were then integrated into the PSS+DM Design Tool aiming to support idea generation for PSS implementation. The tool was tested with students, PSS and/or DM experts, manufacturing companies and design practitioners through two rounds of workshops in order to evaluate its completeness, effectiveness and usability and define recommendations for improvements. Based on the results, the improved final version of the PSS+DM Design Tool was developed, presenting the potential to support idea generation to improve sustainable PSS implementation through integrating DM features in each PSS lifecycle stage.
\end{abstract}

Keywords: product-service system; distributed manufacturing; future scenarios; design tool; design research methodology

\section{Introduction}

The ever-changing global business environment nowadays requires companies to adopt differentiation strategies in order to stay competitive and attract customers. Product-Service System (PSS), which is described as an integrated offering combined of tangible products and intangible services designed to fulfil final customer needs [1,2], enables companies to differentiate their offers through the integration of products and services [3]. An appropriately designed PSS offering has the potential to provide companies with competitive advantage, build strong relationship with customers and, at the same time, improve production processes and consumption patterns towards environmental sustainability $[4,5]$. However, the implementation of PSS offerings requires companies to redesign their business processes and value chains as well as acquire different competences, thus creating a number of obstacles for companies to overcome [6,7]. Key PSS implementation barriers are related to organisational mindset, customer acceptance and a lack of supportive regulations, and affect in particular business-to-customers (B2C) PSS [8-10]. In this paper, authors investigate Distributed Manufacturing (DM) as a promising production model which can be applied to PSS to address some of its implementation barriers. DM is defined as a network of small-scale production units equipped with advanced manufacturing technologies, which facilitate localised and individualised production [11-13]. 
Initial attempts to apply DM principles to PSS can be found in the existing literature [14-25]. However, these attempts are still very fragmented. The majority of authors focus on a small number of individual DM features rather than DM as a whole: e.g., Additive Manufacturing (AM) [17,19], personalisation [14], customer involvement [22] and digital technologies [21,23]. None of the sources address the issue from the PSS perspective and provide a clear identification of existing PSS implementation obstacles along the PSS lifecycle. Ford and Minshall [25] agree that a systematic in-depth analysis of DM application for improved sustainable PSS implementation is missing. In addition, there is a need to translate this knowledge into practically applicable tools to support PSS designers. This research, framed within a three year-long project LeNSin funded by the European Union Erasmus+ programme, aims to fill this knowledge gap by answering the following research question:

How can we practically support the design of PSS offerings through the application of DM principles in order to address PSS implementation barriers?

This paper is structured in nine sections. Section 2 presents the research methodology. Section 3.1 provides a complete list of PSS implementation barriers collected for this research. Section 3.2 introduces the potential of DM and its promising opportunities. Section 3.3 details how DM opportunities can address existing PSS implementation barriers and presents the development of PSS+DM near-future scenarios, as well as their integration into the first version of the PSS+DM Design Tool. Section 3.4 describes the first empirical application of the Tool. Section 3.5 presents the second, improved version of the PSS+DM Design Tool and Section 3.6 describes its empirical testing. Section 3.7 presents the third, revised version of the PSS+DM Design Tool. Finally, Section 4 summarises the research and provides recommendations for future work.

\section{Methodological Framework}

The aim of the research presented in this paper is to develop an idea generation tool to be used to support the design of PSS offerings. Research activities have been planned by adopting the Design Research Methodology (DRM), which is a framework for conducting effective and efficient design research and is especially used for developing design supports [26]. The DRM provides a plan of action for the formulation and assessment of theoretical knowledge and the development and validation of a practical support (in this case a Design Tool) built on these theoretical findings. The DRM approach is particularly relevant for this research, since it frames the collection and analysis of theoretical findings, the development of the design support and the iterative process of its testing, refinement and validation. The research presented in this paper is divided into seven stages: Research Clarification (RC), Descriptive Study I (DS-I), Prescriptive Study I (PS-I), Descriptive Study II (DS-II), Prescriptive Study II (PS-II), Descriptive Study III (DS-III) and Prescriptive Study III (PS-III). Each research stage consists of a number of activities designed to meet specific objectives for the accomplishment of the research aim (Table 1). 
Table 1. Research activities according to the design research methodology (DRM).

\begin{tabular}{|c|c|c|c|}
\hline Section & Research Stage & Research Activities & Objectives Met \\
\hline Section 3.1 & $\begin{array}{l}\text { Research Clarification: } \\
\text { Analysis of existing PSS } \\
\text { implementation barriers }\end{array}$ & Literature review & $\begin{array}{l}\text { 1. Collection of existing PSS } \\
\text { implementation barriers. }\end{array}$ \\
\hline \multirow{3}{*}{ Section 3.2} & \multirow{3}{*}{$\begin{array}{l}\text { Descriptive Study I: } \\
\text { Collection of promising DM } \\
\text { opportunities }\end{array}$} & Literature review & \multirow{3}{*}{$\begin{array}{l}\text { 2. Identification of DM features, } \\
\text { benefits, future trends and } \\
\text { challenges; } \\
\text { 3. Validation of literature review } \\
\text { findings and knowledge update } \\
\text { regarding DM features, benefits, } \\
\text { future trends and challenges. }\end{array}$} \\
\hline & & $\begin{array}{l}\text { Semi-structured } \\
\text { expert interviews }\end{array}$ & \\
\hline & & $\begin{array}{l}\text { DM research } \\
\text { workshop }\end{array}$ & \\
\hline \multirow[b]{2}{*}{ Section 3.3} & \multirow{2}{*}{$\begin{array}{l}\text { Prescriptive Study I: } \\
\text { Development of PSS+DM } \\
\text { near-future scenarios and } \\
\text { the PSS+DM Design Tool } \\
\text { version } 1.0\end{array}$} & $\begin{array}{c}\text { Future scenario } \\
\text { development }\end{array}$ & \multirow{2}{*}{$\begin{array}{l}\text { 4. PSS+DM near-future scenario } \\
\text { development based on the findings } \\
\text { from the RC and DS-I stages; } \\
\text { 5. Integration of PSS+DM scenarios } \\
\text { into the Design Tool version 1.0. }\end{array}$} \\
\hline & & $\begin{array}{l}\text { Development of the } \\
\text { Design Tool } \\
\text { version } 1.0\end{array}$ & \\
\hline \multirow[t]{2}{*}{ Section 3.4} & \multirow[t]{2}{*}{$\begin{array}{l}\text { Descriptive Study II: } \\
\text { Empirical testing of the } \\
\text { PSS+DM Design Tool } \\
\text { version } 1.0\end{array}$} & $\begin{array}{l}\text { Testing of the Design } \\
\text { Tool version } 1.0 \text { with } \\
\text { design students }\end{array}$ & \multirow[t]{2}{*}{$\begin{array}{l}\text { 6. Evaluation of usability and } \\
\text { effectiveness of the PSS+DM Design } \\
\text { Tool version 1.0. }\end{array}$} \\
\hline & & Data analysis & \\
\hline Section 3.5 & $\begin{array}{l}\text { Prescriptive Study II: } \\
\text { Development of the } \\
\text { PSS+DM Design Tool } \\
\text { version } 2.0\end{array}$ & $\begin{array}{l}\text { Development of the } \\
\text { Design Tool } \\
\text { version } 2.0\end{array}$ & $\begin{array}{l}\text { 7. Summary of the requirements for } \\
\text { the development of the improved } \\
\text { version of the Design Tool. } \\
\text { 8. Updated design of the Tool. }\end{array}$ \\
\hline \multirow{3}{*}{ Section 3.6} & \multirow{3}{*}{$\begin{array}{l}\text { Descriptive Study III: } \\
\text { Empirical testing of the } \\
\text { PSS+DM Design Tool } \\
\text { version } 2.0\end{array}$} & $\begin{array}{l}\text { Testing with PSS } \\
\text { and/or DM experts }\end{array}$ & \multirow{3}{*}{$\begin{array}{l}\text { 9. Evaluation of completeness, } \\
\text { effectiveness, and usability of the } \\
\text { PSS+DM Design Tool version 2.0. }\end{array}$} \\
\hline & & $\begin{array}{l}\text { Testing with } \\
\text { manufacturing } \\
\text { companies and } \\
\text { design agencies }\end{array}$ & \\
\hline & & Data analysis & \\
\hline Section 3.7 & $\begin{array}{l}\text { Prescriptive Study III: } \\
\text { Development of the final } \\
\text { version of the PSS+DM } \\
\text { Design Tool }\end{array}$ & $\begin{array}{l}\text { Development of the } \\
\text { Design Tool } \\
\text { version } 3.0\end{array}$ & $\begin{array}{l}\text { 10. Summary of the requirements } \\
\text { for the development of the } \\
\text { improved version of the Design Tool. } \\
\text { 11. Updated design of the Tool. }\end{array}$ \\
\hline
\end{tabular}

Research Clarification (RC): Analysis of existing PSS implementation barriers. The initial research stage required an extensive understanding of the PSS implementation barriers. The DRM suggests that a relevant literature review must be used to clarify the current understanding and identify the state-of-the-art. A literature review method was applied for collecting, analysing and making a complete list of existing obstacles preventing successful PSS implementation. In addition, existing attempts to apply DM to PSS were reviewed to identify the potential of DM to address the collected PSS implementation barriers.

Descriptive Study I (DS-I): Collection of promising DM opportunities. The second stage of the research aimed at identifying current and future potential DM opportunities and challenges (with a 10-year timeframe). In order to do so, a literature review was carried out as the key research method used in DS-I [26]. However, the literature on DM, as a rapidly evolving field, was observed to be limited and two empirical studies were conducted to address this limitation [26]. Following the literature review, semi-structured interviews were carried out with 10 experts, selected from the literature combining DM and PSS. The second study was the research workshop on DM, organised by the University of Oxford, which invited 18 participants including one of the authors who got involved in group activities and discussions. These methods allowed the authors to validate the literature review findings, complement them with the most up-to-date knowledge, and, most importantly, identify specific DM near-future trends for the next 10 years that could not be found in the literature. 
Prescriptive Study I (PS-I): Development of PSS+DM near-future scenarios and the PSS+DM Design Tool version 1.0. According to the DRM, PS-I aims at developing a design support (e.g., guidelines, methods, tools, etc.) in order to improve the existing situation using the knowledge obtained in previous research stages [26]. In the case of this research, data gathered during the RC stage and the DS-I stage have been used to develop a design support-the PSS+DM Design Tool. This tool was made of a set of PSS+DM near-future scenarios which were developed by coupling collected PSS implementation barriers (RC) with DM opportunities (DS-I) by applying the theory building approach [27] using the cognitive mapping method [28]. These near-future scenarios were then integrated in a range of Scenario Cards aimed at triggering idea generation and categorised on the Innovation Diagram made of key dimensions of PSS and DM, forming the first version of the tool. Based on the DRM, the authors adopted the following evaluation criteria for the PSS+DM Design Tool: (1) Effectiveness (can the tool be used for the task?): the extent to which the tool enables users to generate ideas for DM applied to PSS; (2) Usability (do users understand the tool and can use it?): the extent to which the tool is easy to understand and apply; and (3) Completeness (are the contents of the tool logical and detailed enough to address its function?): the extent to which the tool contains valid information about PSS and DM. The empirical evaluation studies were organised to receive feedback from the target users of the tool: industry professionals and design practitioners.

Descriptive Study II (DS-II): Empirical testing of the PSS+DM Design Tool version 1.0. The empirical application of the first version of the PSS+DM Design Tool has been completed with 45 undergraduate and postgraduate students from various design-related backgrounds. The study was meant to be the pilot application of the Tool, and was a part of a two-week pilot course organised by the LeNSin project which invited students from relevant design backgrounds with basic knowledge of PSS and DM. The testing was carried out to evaluate the tool's effectiveness and usability. The completeness aspect was not evaluated with students because of their lack of comprehensive knowledge about PSS and DM to provide advice on improvements of the tool's contents. The study consisted of a one-day design workshop, which was organised to simulate the practical application of the tool. During the workshop students had to apply the tool to generate ideas for integrating DM principles into their initial PSS concepts. Qualitative data was collected through the questionnaires with open-ended questions, verbal feedbacks, analysis of generated ideas, and authors' observations on design dynamics during the use of the tool. Qualitative data were analysed using thematic coding, i.e., classifying data into codes and later into themes in order to generalise gathered insights and ideas [29]. Quantitative data were collected through closed-ended scale questions in questionnaires and analysed using a prescriptive statistics percentage tool used to identify the proportion of people who gave a particular evaluation [30]. Quantitative and qualitative data have been analysed side-by-side in order to compare the findings. For example, if scale questions showed that the majority of the respondents identified a specific feature as non-satisfactory, the thematic coding method allowed identifying the aspects of that particular feature that need further improvements.

Prescriptive Study II (PS-II): Development of the PSS+DM Design Tool version 2.0. Qualitative and quantitative data collected and analysed during the DS-II stage were grouped to define strengths and weaknesses of the Tool. These data were then clustered in recommendations for the improved existing and new features to be integrated into the next version of the Design Tool. Based on these recommendations, the updated PSS+DM Design Tool version 2.0. was developed.

Descriptive Study III (DS-III): Empirical testing of the PSS+DM Design Tool version 2.0. The empirical application of the second version of the PSS+DM Design Tool has been carried out with 10 experts from PSS and/or DM-related fields, four manufacturing companies and two design agencies and aimed at evaluating the Tool's completeness, effectiveness and usability. Experts were invited to face-to-face mini workshops, lasting up to two hours, where they were asked to get familiar with each element of the tool and provide feedback using questionnaires. Testing with experts, who were mostly the authors of the papers analysing PSS and/or DM, allowed participants to discuss the contents of the tool with people who have expertise on both focus fields and was particularly useful for the 
evaluation of the completeness aspect of the tool. Manufacturing companies and design agencies attended workshops during which they applied the Tool to improve existing or to design new PSS offerings. Selected companies were of various sizes, from different industries, and employed people with various expertise thus enabling to test the versatility of the tool. Selected design agencies worked on ongoing PSS projects. Data collection methods included questionnaires, analysis of ideas generated using the tool and authors' observations on design dynamics. The same data analysis and application methods as in the DS-II stage were applied to maintain consistency.

Prescriptive Study III (PS-III): Development of the final version of the PSS+DM Design Tool. The final study, described in this paper, aimed at revising the second version of the tool based on the insights gained from the DS-III stage. Applying the same data collection and analysis methods as in the PS-II stage, recommendations for the improved existing and new features were defined. This resulted in the development of the final version of the PSS+DM Design Tool with improved layout and contents.

\section{Results and Discussion}

\subsection{Research Clarification (RC): Analysis of Existing PSS Implementation Barriers}

The goal of the literature review was to collect existing barriers which hinder companies from successful PSS implementation. Keywords Product-Service Systems, Servitisation, Service Transformation, Functional Sales, Performance Economy and Barrier, Limitation, Obstacle were used to search for books, peer-reviewed journal papers, conference articles and $\mathrm{PhD}$ theses. The choice of these keywords was based on the keywords used by Baines et al. [2] and Tukker [31]. The documents were searched for through Scopus and Google Scholar search engines. Forty-two sources describing PSS implementation barriers were selected to collect barriers for this research. All the papers were analysed in chronological sequence and, in total, 48 barriers were collected. Collected barriers have been grouped according to three categories introduced by the United Nations Environmental Programme (UNEP) [32] and Mont and Lindhqvist [33]: (1) PSS barriers for companies; (2) PSS barriers for customers, and (3) Context-related PSS barriers. The following text describes barriers in each category and Table 2 provides a detailed list of barriers collected for this research and subcategorised according to Ceschin [34].

Table 2. Product-Service Systems (PSS) implementation barriers.

\begin{tabular}{|c|c|c|c|}
\hline No. & Subcategory & PSS Implementation Barriers & $\begin{array}{l}\text { Literature } \\
\text { Source }\end{array}$ \\
\hline \multicolumn{4}{|c|}{ PSS barriers for companies: } \\
\hline 1 & \multirow{4}{*}{$\begin{array}{l}\text { Organisational } \\
\text { mind-set }\end{array}$} & $\begin{array}{l}\text { Challenges to adopt mutual PSS-oriented mindset and embed } \\
\text { PSS culture. }\end{array}$ & {$[32,36,37]$} \\
\hline 2 & & $\begin{array}{l}\text { Resistance to change and adapting new ways to manage } \\
\text { business processes. }\end{array}$ & {$[6,36,39]$} \\
\hline 3 & & $\begin{array}{l}\text { Resistance to make long-term decisions needed for PSS } \\
\text { implementation. }\end{array}$ & {$[35,52]$} \\
\hline 4 & & $\begin{array}{l}\text { Inability to capture the value of PSS in a successful business } \\
\text { model. }\end{array}$ & [37] \\
\hline 5 & \multirow{4}{*}{$\begin{array}{l}\text { Knowledge and } \\
\text { expertise }\end{array}$} & $\begin{array}{l}\text { A lack of know-how, knowledge, and expertise in methods and } \\
\text { tools needed to develop, evaluate, and deliver a competent PSS. }\end{array}$ & {$[2,7,35]$} \\
\hline 6 & & A lack of skilled personnel in service development. & {$[32,40,41,52]$} \\
\hline 7 & & $\begin{array}{l}\text { A lack of know-how of designing and developing a product for } \\
\text { PSS offerings. }\end{array}$ & {$[32,38,39]$} \\
\hline 8 & & Overemphasis on product innovation. & {$[36,37,39]$} \\
\hline 9 & \multirow{3}{*}{$\begin{array}{l}\text { Finance-related } \\
\text { challenges }\end{array}$} & $\begin{array}{l}\text { A lack of financial resources of SMEs to implement and run PSS } \\
\text { business models. }\end{array}$ & {$[6,51]$} \\
\hline 10 & & Challenges to cover the initial investment in PSS development. & {$[5,6,40]$} \\
\hline 11 & & $\begin{array}{l}\text { A lack of knowledge and practice in pricing PSS offerings, } \\
\text { estimating cash flows and financial savings. }\end{array}$ & {$[2,35,38,40]$} \\
\hline
\end{tabular}


Table 2. Cont.

\begin{tabular}{|c|c|c|c|}
\hline No. & Subcategory & PSS Implementation Barriers & $\begin{array}{l}\text { Literature } \\
\text { Source }\end{array}$ \\
\hline \multicolumn{4}{|c|}{ PSS barriers for companies: } \\
\hline 12 & \multirow{4}{*}{$\begin{array}{l}\text { Organisational } \\
\text { fragmentation }\end{array}$} & $\begin{array}{l}\text { Organisational and structural separation between product and } \\
\text { service designs. }\end{array}$ & [39] \\
\hline 13 & & Disagreements between organisational bodies. & {$[36,39,53]$} \\
\hline 14 & & Risk of cannibalisation. & {$[7,35,54]$} \\
\hline 15 & & Challenges of adding services to some products. & [38] \\
\hline 16 & \multirow{4}{*}{$\begin{array}{l}\text { Collaboration } \\
\text { with stakeholders }\end{array}$} & $\begin{array}{l}\text { Concerns linked to sharing knowledge, expertise, and } \\
\text { confidential information about internal procedures. }\end{array}$ & {$[4,41,52]$} \\
\hline 17 & & $\begin{array}{l}\text { A multiplicity of actors in service chains, none of whom may } \\
\text { have an overview of the entire chain and/or the ability to } \\
\text { influence other actors. }\end{array}$ & {$[7,32,35]$} \\
\hline 18 & & $\begin{array}{l}\text { Concerned of weakened administration of core competencies } \\
\text { caused by co-dependence of partners. }\end{array}$ & {$[7,32,55]$} \\
\hline 19 & & $\begin{array}{l}\text { Concerns linked to conflict of economic interest caused by } \\
\text { different partners. }\end{array}$ & {$[4,51]$} \\
\hline 20 & \multirow{5}{*}{$\begin{array}{l}\text { Relationship with } \\
\text { customers }\end{array}$} & $\begin{array}{l}\text { Challenging to define customers' purchase and service } \\
\text { acceptance behaviour and develop PSS for a specific context. }\end{array}$ & {$[42,53,56]$} \\
\hline 21 & & $\begin{array}{l}\text { Concerns of the requirement for PSS provider to access } \\
\text { customers' personal data or even enter into their property. }\end{array}$ & {$[33,50,57]$} \\
\hline 22 & & $\begin{array}{l}\text { Difficulties to provide PSS with higher or equal level of } \\
\text { performance than traditional solutions. }\end{array}$ & {$[36,38]$} \\
\hline 23 & & Ownerless consumption might lead to careless behaviour. & {$[38,40,58]$} \\
\hline 24 & & $\begin{array}{l}\text { Challenges of customers not being willing to return the product } \\
\text { at the end of contract. }\end{array}$ & {$[5,42]$} \\
\hline 25 & \multirow{2}{*}{$\begin{array}{l}\text { Maintenance } \\
\text { services }\end{array}$} & $\begin{array}{l}\text { Difficulties in managing components for maintenance service } \\
\text { caused by the lack of global service infrastructure. }\end{array}$ & {$[52,59]$} \\
\hline 26 & & A lack of data of PSS lifecycle. & {$[5,39,52]$} \\
\hline 27 & \multirow{4}{*}{$\begin{array}{l}\text { Environmental } \\
\text { concerns }\end{array}$} & Difficulties to quantify environmental saving of PSS acceptance. & [32] \\
\hline 28 & & $\begin{array}{l}\text { Prolonged time-to-market caused by the environmental } \\
\text { efficiency added to business. }\end{array}$ & {$[5,52]$} \\
\hline 29 & & An environmental impact caused by service provision. & {$[52,60]$} \\
\hline 30 & & Absence of "green" suppliers. & [51] \\
\hline \multicolumn{4}{|c|}{ PSS barriers for customers: } \\
\hline 31 & \multirow{3}{*}{$\begin{array}{l}\text { Mind-set and } \\
\text { social status }\end{array}$} & $\begin{array}{l}\text { A belief that product ownership is related to social status and } \\
\text { measure of achievement in life. }\end{array}$ & {$[6,41,42,44,45,58]$} \\
\hline 32 & & $\begin{array}{l}\text { A belief that high initial investment when purchasing a product } \\
\text { guarantees high level of satisfaction. }\end{array}$ & {$[2,41,45,58]$} \\
\hline 33 & & A lack of recognisable PSS brand. & {$[50,61]$} \\
\hline 34 & \multirow{2}{*}{$\begin{array}{l}\text { Knowledge about } \\
\text { PSS }\end{array}$} & $\begin{array}{l}\text { A lack of understanding about the overall PSS concept and a } \\
\text { belief that PSS solutions are less comfortable. }\end{array}$ & {$[38,42,45,46,50]$} \\
\hline 35 & & $\begin{array}{l}\text { A lack of information about owned product lifecycle costs and a } \\
\text { belief that service "package" is more expensive }\end{array}$ & {$[33,42,43,45]$} \\
\hline 36 & \multirow{4}{*}{$\begin{array}{l}\text { Relationship with } \\
\text { PSS provider }\end{array}$} & A lack of trust in PSS provider & {$[43,49,58]$} \\
\hline 37 & & Resistance to accept long-term relationship with PSS provider. & {$[35,47,54,58]$} \\
\hline 38 & & $\begin{array}{l}\text { A mismatch between the offerings of PSS companies and the } \\
\text { needs or desires of their potential customers. }\end{array}$ & {$[36,47,58,62]$} \\
\hline 39 & & $\begin{array}{l}\text { Concerned about the requirement for PSS provider to access } \\
\text { customers' personal data. }\end{array}$ & {$[38,50]$} \\
\hline 40 & \multirow{3}{*}{$\begin{array}{l}\text { Use of product or } \\
\text { access to services }\end{array}$} & $\begin{array}{l}\text { Concerns linked to independence and convenience related to } \\
\text { the access of shared products. }\end{array}$ & {$[4,45,63]$} \\
\hline 41 & & Concerns related to hygiene of used or shared products. & {$[42,48,49]$} \\
\hline 42 & & Concerns related to ruining or damaging shared products. & {$[42,43,45,58]$} \\
\hline \multicolumn{4}{|c|}{ Context-related PSS barriers: } \\
\hline 43 & \multirow{4}{*}{$\begin{array}{l}\text { Finance-related } \\
\text { challenges }\end{array}$} & Taxation & {$[40,54]$} \\
\hline 44 & & A lack of knowledge and support from financial institutions. & {$[33,51]$} \\
\hline 45 & & $\begin{array}{l}\text { Low cost of resources, which encourage manufacturing of } \\
\text { products using raw materials instead of recycling. }\end{array}$ & {$[38,64]$} \\
\hline 46 & & $\begin{array}{l}\text { High labour prices, which prevent customers from choosing } \\
\text { labour-intensive PSS offerings. }\end{array}$ & {$[34,38]$} \\
\hline 47 & \multirow{2}{*}{$\begin{array}{l}\text { Regulatory } \\
\text { barriers }\end{array}$} & A lack of external infrastructure for product end-of-life stage. & {$[32,50,52]$} \\
\hline 48 & & $\begin{array}{l}\text { Externalities (environmental impacts) not included in the } \\
\text { market price. }\end{array}$ & [33] \\
\hline
\end{tabular}


PSS barriers for companies. Business transformation towards a servitised model requires companies to adopt a PSS-oriented mindset and prepare to make long-term decisions needed for PSS implementation [32,35-37]. PSS adoption requires companies to have a wide range of expertise in the methods and tools needed to develop, deliver and manage PSS offerings [32,38,39]. Another set of barriers for companies are caused by financial concerns, which are often the reason why companies perceive PSS as a riskier business model than merely selling products [5,40]. Companies might lack practice and knowledge in covering initial investment, pricing PSS offerings and estimating cash flows in an unfamiliar system of gaining profits [35,38]. Further barriers faced by companies are related to collaborating with a number of partners along the value chain. Cooperation with stakeholders causes fears linked to organisational fragmentation, reduction of competences, and safety of confidential information of companies $[4,7,35,41]$. Not only cooperation with business partners, but also relationships with customers are challenging for companies. Customers' purchase and service acceptance behaviour is complicated and highly under-researched with a strong belief that ownership of the product brings the customer a number of functional and status benefits [5,42]. When delivering PSS, companies might fail to provide PSS offerings with higher or equal level of performance than traditional product-based solutions [36,38].

PSS barriers for customers. Barriers for customers are predominantly linked to business-toconsumer (B2C) markets, since industrial companies in the business-to-business (B2B) area face fewer obstacles in accepting PSS offerings [43]. The reason why customers might find it difficult to switch to ownerless consumption is the belief that product ownership brings better comfort and is related to social status $[41,42,44,45]$. In general, customers lack understanding and knowledge about the overall PSS concepts, which causes anxiety of not knowing what to expect from PSS offerings [38,42,46]. What is more, customers lack knowledge about lifecycle costs of owned products and believe that accepting a servitised solution is more expensive $[4,42,43,45]$. As a result, some customers are concerned of undertaking a long-term relationship with a PSS provider $[35,47]$. Use of shared products can raise customers' concerns regarding hygiene and independence related to access of the product $[42,48,49]$. Finally, customers might face privacy issues because certain types of PSS require service providers to access personal information or even enter into customer's property $[39,50]$.

Context-related PSS barriers. Authors agree that there is a lack of specific regulations to support PSS implementation [33,51]. Financial institutions, lacking knowledge about overall PSS, are in some cases not willing to support PSS implementation [33,40,48,51]. Mont and Lindhqvist [33] emphasize that some hidden environmental and social costs, so called 'externalities', not included in market prices slow down PSS business implementation. Low costs of manufacturing resources and high labour prices encourage the development of product-oriented offerings $[5,40,48]$. Finally, companies face overall lack of external support and infrastructure for the product end-of-life stage including collection, recycling, and remanufacturing [32,50,52].

Existing attempts by other authors to apply DM features to PSS implementation show the potential of DM to address some of the above-mentioned barriers. According to Reim et al. [15], links between DM network partners facilitate companies' involvement in service provision and support maintenance of PSS offerings. Arup and Sinclair et al. [16,22] describe DM as a liberalisation of manufacturing enabling customer involvement in design, repair, and support of products included in PSS offerings, thus facilitating PSS companies in identifying and addressing customer needs. In addition, Despeisse and Ford [17] describe the opportunity of AM, one of the key DM enablers, to develop personalised and bespoke products and services. The insights from the existing literature suggested a range of potential opportunities arising from applying DM to PSS. This prompted the authors to investigate the full spectrum of opportunities and understand how these could be translated in a practical tool to design PSS offerings. In particular, the focus of the tool is on integrating PSS and DM principles to enable practitioners to design PSS offerings capable of addressing the known PSS implementation barriers. Thus, the supposed success factor of this tool would be increased competitiveness of companies due to increased successful implementation rate of PSS offerings. 


\subsection{Descriptive Study I (DS-I): Collection of Promising DM Opportunities}

Prospective DM opportunities presented in this section are summarised from gathered DM benefits and future trends for up to 10 years' time. First of all, a literature review has been carried out. This included 37 sources describing DM and its potential opportunities. It was identified that the literature on DM is still fragmented, lacking a comprehensive overview of DM benefits and challenges, and thus providing limited insights on current and future trends and developments. In order to validate the literature review findings and update them with the most recent knowledge, expert interviews and research workshops have been conducted. Interviews were carried out with 10 academics and industry professionals from DM-related fields and lasted around one hour each. Participants were introduced to literature review findings regarding DM benefits, challenges, and future trends and asked to agree or disagree on presented findings. Later, experts were asked to explain their opinions and add missing benefits, challenges, and trends from their own experience. A DM research workshop organised by the University of Oxford took $8 \mathrm{~h}$ and involved 18 researchers, including one of the authors, working on DM-related research projects. Firstly, researchers delivered presentations with their most recent findings. Secondly, all participants were divided into groups to discuss questions about DM opportunities, challenges, and future trends. A collective discussion carried out at the end of the workshop helped the participating author identify that some of the discussed opportunities, challenges, and future trends were new compared to existing literature.

All DM opportunities, collected through the literature review, expert interviews, and the research workshop, have been classified based on the categorisations introduced by Srai et al., Bessière et al. and Kumar et al. $[12,65,66]$ : application of digital and physical technologies, localisation of manufacturing units and customer-orientation (personalisation). Application of digital and physical technologies refers to the use of manufacturing hardware (such as Additive Manufacturing (AM) or Computer Numerical Control (CNC) machinery), and data capturing and transferring equipment (such as Information-Communication Technologies (ICT) or sensors) [12,67]. Localisation of manufacturing units refers to the close proximity between manufacturing facilities and customers or manufacturing resources [68,69]. Customer-orientation refers to personalisation of products and services according to customer needs $[18,67]$. Along with DM opportunities, this section summarises DM challenges, which potentially hinder successful DM adoption.

Application of digital and physical technologies. Comprehensive collaboration between manufacturing units is a crucial requirement for successful development and diffusion of DM, which can be achieved through digitisation of manufacturing processes [12]. Kühnle [70] describes the importance of ICT to enable companies to adapt and integrate manufacturing process within an organisation and across collaborative partners. It has been emphasized by the research workshop participants that the adoption of digital technologies has the potential to support all product lifecycle stages. Moreover, digital connectivity allows companies to share production files in order to spread workloads across a number of manufacturing facilities and even remotely control manufacturing equipment [12,71]. The application of sensor technology shows the potential to facilitate production and consumption as well as development of future products [12,72]. Expert interviews identified that the adoption of AM provides companies with an ability to produce complex products and their components in small lot sizes. Moreover, the design requirements for AM encourage companies to save resources and produce products with a focus on their end-of-life [18,25]. The development of $4 \mathrm{D}$ printing technology that enables production of transformable 3D shapes responsive to stimulus, such as heat and water, offers product volume reduction, self-disassembly, and self-repair of product components [73,74]. AM experts forecasted that the evolution of adoption of advanced manufacturing equipment shows the potential for the development of desktop manufacturing machinery for home use.

However, some of the most significant challenges for DM implementation are cybernetic security and privacy issues related to companies' and customers' data caused by digitisation and application of ICT $[67,70,75]$. Research workshop participants confirmed that the lack of official data-sharing agreements increases the risk of illegal copying of objects through access to digital files and open-source 
information [12,76]. Participants also agreed that AM technologies can be costly for companies to implement, maintain, operate and upgrade [12]. Perception that 3D printed products are not reliable can hinder customers from accepting them [Expert interviews].

Localisation of manufacturing units. Distributing manufacturing to small-scale localised production units helps companies achieve resilience in terms of market and environmental changes ([61], Expert interviews) and makes manufacturing processes more effective, with reduced number of operations and scalable product variety $[12,68]$. Localisation of manufacturing also benefits companies with reduced transportation (logistic) costs and shorter delivery times [8,75,77]. Both expert interviews and research workshops suggested that manufacturing in local makerspaces, home-workshops and on a high street provides a chance to produce goods and spare parts at the point of need [75,78]. Localisation of manufacturing brings the potential for SMEs to get integrated into bigger values chains [Expert interviews] and enables developing countries to produce products in their own demand [12,68,71].

However, companies have to adopt a DM-oriented mindset in order to transform their businesses towards distribution of manufacturing units [68]. Experts confirmed that regulating a small number of large-scale productions is easier than regulating a large number of small production units [68]. Localisation of manufacturing units also causes challenges related to their adoption to local context [Research workshop]. Finally, same quality maintenance and control of delivery at various manufacturing units are both costly and difficult to manage [12].

Customer-orientation. DM provides companies with resilience to changes in demand caused by moving from centralised production of a single product to a small-scale production of personalised products ([12,67], Expert interviews, Research workshop). Customers are able to get involved in product development processes both digitally, through the Internet $[12,67,79]$ and physically, in makerspaces and home-workshops [Expert interviews]. This type of user involvement creates win-win solutions for companies getting familiar with their customer needs and customers aiming to receive goods produced especially for them. Research workshop participants and Srai et al. [12] emphasised that companies' ability to offer personalised/bespoke products and services creates a long-lasting relationship with their customers. Finally, DM has the potential to encourage a new generation of knowledgeable customers, with a better understanding how products are made and how to use them most efficiently ([12], Expert interviews).

However, a small-scale, on-demand production is less efficient compared to the centralised mass production [69] and requires customers to pay more for personalised/bespoke products and services [12]. Experts emphasised that companies have to encourage their customers to get involved in manufacturing processes and adopt the new system of producing and consuming. Moreover, manufacturing in makerspaces or home-workshops is restricted in manpower, tools, and investment capacity, resulting in a limited type of products to be able to be produced [80]. Finally, there is a risk to increase environmental impact caused by the move from consumption of products to consumption of production with more people getting involved in manufacturing processes [Expert interviews].

It can be summarised that the majority of literature review findings were confirmed by the experts and research workshop attendees: they validated $86 \%$ of collected DM opportunities and $70 \%$ of DM challenges. Only literature review findings validated by the participants of either study have been integrated in the following research steps and summarised in Table 3. 
Table 3. DM opportunities and corresponding challenges.

\begin{tabular}{|c|c|c|c|c|}
\hline No. & DM Opportunities & $\begin{array}{l}\text { Literature } \\
\text { Source }\end{array}$ & DM Challenges & $\begin{array}{l}\text { Literature } \\
\text { Source }\end{array}$ \\
\hline \multicolumn{5}{|c|}{ Application of digital and physical technologies: } \\
\hline 1 & $\begin{array}{l}\text { ICT-facilitated collaboration between } \\
\text { geographically dispersed } \\
\text { stakeholders. }\end{array}$ & {$[70,71]$} & \multirow{2}{*}{$\begin{array}{l}\text { Challenges related to information } \\
\text { exchange, communication and } \\
\text { control between different } \\
\text { production sites. }\end{array}$} & \multirow[t]{2}{*}{ [75] } \\
\hline \multirow{2}{*}{2} & Spread of workloads across & \multirow{2}{*}{ [12] } & & \\
\hline & $\begin{array}{l}\text { manufacturing units sharing same } \\
\text { digital standards. }\end{array}$ & & \multirow{2}{*}{$\begin{array}{l}\text { Managers receive greater } \\
\text { responsibilities and difficulties } \\
\text { caused by complex manufacturing } \\
\text { tasks. }\end{array}$} & \multirow[t]{2}{*}{ [75] } \\
\hline 3 & $\begin{array}{l}\text { Remote control of manufacturing } \\
\text { equipment. }\end{array}$ & {$[71]$} & & \\
\hline 4 & $\begin{array}{l}\text { Opportunity to start selling } \\
\text { technological knowledge instead of } \\
\text { providing physical manufacturing } \\
\text { service. }\end{array}$ & $\begin{array}{c}{[\text { Expert }} \\
\text { interviews] }\end{array}$ & $\begin{array}{l}\text { Lack of official data-sharing } \\
\text { agreements between digitally } \\
\text { connected supply chain actors. }\end{array}$ & {$[12,76]$} \\
\hline 5 & $\begin{array}{l}\text { Improved monitoring, control and } \\
\text { optimisation of stock and material } \\
\text { flows. }\end{array}$ & [12] & \multirow{3}{*}{$\begin{array}{l}\text { Challenges related to fitting new } \\
\text { technologies into existing } \\
\text { companies' production lines. }\end{array}$} & \multirow{3}{*}{ [67] } \\
\hline 6 & $\begin{array}{l}\text { Improved product monitoring } \\
\text { through the application of sensor } \\
\text { technology. }\end{array}$ & [12] & & \\
\hline 7 & $\begin{array}{l}\text { Optimised production, consumption } \\
\text { and service through the application of } \\
\text { sensor technology. }\end{array}$ & [70] & & \\
\hline 8 & Machine to machine communication & [Expert & \multirow{4}{*}{$\begin{array}{l}\text { Security issues related to } \\
\text { companies' and customers' data. }\end{array}$} & \multirow{4}{*}[67,70]{} \\
\hline 9 & $\begin{array}{l}\text { Improved development of future } \\
\text { products through the application of } \\
\text { "Digital Brain". }\end{array}$ & {$[72]$} & & \\
\hline 10 & $\begin{array}{l}\text { Functional products achieved through } \\
\text { the application of sensor technology. }\end{array}$ & $\begin{array}{c}\text { [Expert } \\
\text { interviews] }\end{array}$ & & \\
\hline 11 & $\begin{array}{l}\text { Better understanding of user } \\
\text { behaviour through the Big Data } \\
\text { collected by sensors. }\end{array}$ & [81] & & \\
\hline 12 & $\begin{array}{l}\text { Potential reduction of the } \\
\text { time-to-market through the ability to } \\
\text { manufacture in small lot sizes. }\end{array}$ & [75] & $\begin{array}{l}\text { High initial investment costs, } \\
\text { related to adoption of new } \\
\text { technologies, their maintenance } \\
\text { and upgrade. }\end{array}$ & [12] \\
\hline 13 & $\begin{array}{l}\text { Small-scale production of more } \\
\text { complex products and their } \\
\text { components provided by AM. }\end{array}$ & $\begin{array}{c}\text { [Expert } \\
\text { interviews] }\end{array}$ & \multirow{3}{*}{$\begin{array}{l}\text { Energy consumption of advanced } \\
\text { manufacturing technology is } \\
\text { higher per unit. }\end{array}$} & \multirow{3}{*}{$\begin{array}{l}\text { [Expert } \\
\text { interviews] }\end{array}$} \\
\hline 14 & $\begin{array}{l}\text { Consumption of less material and less } \\
\text { waste at the point of manufacturing } \\
\text { using AM. }\end{array}$ & [25] & & \\
\hline 15 & $\begin{array}{l}\text { Optimisation of recycling in order to } \\
\text { enable circular economy using AM. }\end{array}$ & {$[18,25]$} & & \\
\hline 16 & $\begin{array}{l}\text { enable circular economy using AM. } \\
\text { Simplified and optimised design of } \\
\text { products produced using AM. }\end{array}$ & [25] & \multirow{4}{*}{$\begin{array}{l}\text { Challenges related to training of } \\
\text { employees who are required to } \\
\text { have a wide range of technical } \\
\text { and design skills. }\end{array}$} & \multirow{4}{*}[12,69]{} \\
\hline 17 & $\begin{array}{l}\text { Manufacturing of lightweight } \\
\text { products using AM. }\end{array}$ & {$[19,82]$} & & \\
\hline 18 & $\begin{array}{l}\text { Self-disassembly and self-repair of } \\
\text { product components available with } \\
\text { the application of } 4 \mathrm{D} \text { printing } \\
\text { technology. }\end{array}$ & [73] & & \\
\hline 19 & $\begin{array}{l}\text { Volume reduction of packed } 4 \mathrm{D} \\
\text { printed products. }\end{array}$ & [73] & & \\
\hline 20 & $\begin{array}{l}\text { Low cost desktop 3D printers } \\
\text { equipped with advanced materials } \\
\text { (e.g., metal powder). }\end{array}$ & $\begin{array}{l}\text { [Expert } \\
\text { interviews] }\end{array}$ & $\begin{array}{l}\text { Perception that 3D printing } \\
\text { certain components is not reliable. }\end{array}$ & $\begin{array}{l}\text { [Expert } \\
\text { interviews] }\end{array}$ \\
\hline
\end{tabular}


Table 3. Cont.

\begin{tabular}{|c|c|c|c|c|}
\hline No. & DM Opportunities & $\begin{array}{l}\text { Literature } \\
\text { Source }\end{array}$ & DM Challenges & $\begin{array}{l}\text { Literature } \\
\text { Source }\end{array}$ \\
\hline \multicolumn{5}{|c|}{ Localisation of manufacturing units: } \\
\hline 21 & $\begin{array}{l}\text { Reduced transportation costs and } \\
\text { delivery times. }\end{array}$ & {$[75,77]$} & \multirow{3}{*}{$\begin{array}{l}\text { Difficulties related to managing } \\
\text { same quality delivery at various } \\
\text { manufacturing units. }\end{array}$} & \multirow{3}{*}{ [12] } \\
\hline 22 & $\begin{array}{l}\text { Reduced environmental impact of } \\
\text { transportation, caused by only digital } \\
\text { production files and raw materials } \\
\text { being shipped over long distanced. }\end{array}$ & [83] & & \\
\hline 23 & $\begin{array}{l}\text { Last mile low-emission delivery } \\
\text { implemented by companies to their } \\
\text { customers. }\end{array}$ & {$[12,19]$} & & \\
\hline 24 & $\begin{array}{l}\text { Manufacturing in real time at the } \\
\text { point of need. }\end{array}$ & $\begin{array}{l}\text { [Expert } \\
\text { interview, } \\
\text { Research } \\
\text { workshop] }\end{array}$ & \multirow[t]{2}{*}{$\begin{array}{l}\text { Regulating small number of } \\
\text { large-scale productions is easier } \\
\text { than regulating a large number of } \\
\text { small production sites. }\end{array}$} & \multirow[t]{2}{*}[68]{} \\
\hline \multirow{2}{*}{25} & \multirow{2}{*}{$\begin{array}{l}\text { Reduction of the number of } \\
\text { intermediaries in the supply chain. }\end{array}$} & \multirow{2}{*}{ [84-86] } & & \\
\hline & & & \multirow{4}{*}{$\begin{array}{l}\text { Issues related to energy } \\
\text { consumption and toxicity of 3D } \\
\text { printing processes. }\end{array}$} & \multirow{4}{*}{$\begin{array}{c}\text { [Expert } \\
\text { interviews }\end{array}$} \\
\hline 26 & $\begin{array}{l}\text { Combination of production and } \\
\text { entertainment in manufacturing } \\
\text { facilities in public spaces. }\end{array}$ & $\begin{array}{l}\text { [Expert } \\
\text { interviews] }\end{array}$ & & \\
\hline 27 & $\begin{array}{l}\text { Production in-store with } \\
\text { manufacturing units on high street. }\end{array}$ & [78] & & \\
\hline 28 & $\begin{array}{l}\text { Home manufacturing of products } \\
\text { which are no longer produced by } \\
\text { companies. }\end{array}$ & $\begin{array}{l}\text { [Expert } \\
\text { interviews, } \\
\text { Research } \\
\text { workshop] }\end{array}$ & & \\
\hline \multirow[t]{2}{*}{29} & \multirow{2}{*}{$\begin{array}{l}\text { Production of products and their } \\
\text { components carried out anywhere in } \\
\text { the world using local resources and } \\
\text { access to technologies. }\end{array}$} & \multirow[t]{2}{*}[12]{} & $\begin{array}{l}\text { Challenges to sensibly adapt new } \\
\text { manufacturing units to the local } \\
\text { context. }\end{array}$ & $\begin{array}{l}\text { [Research } \\
\text { workshop] }\end{array}$ \\
\hline & & & \multirow{3}{*}{$\begin{array}{l}\text { Difficulties and costs needed to } \\
\text { manage production quality at } \\
\text { various manufacturing units. }\end{array}$} & \multirow{3}{*}{ [12] } \\
\hline 30 & $\begin{array}{l}\text { Re-evaluation of a global network } \\
\text { design of companies. }\end{array}$ & [67] & & \\
\hline \multirow{2}{*}{31} & \multirow{2}{*}{$\begin{array}{l}\text { Potential open collaboration between } \\
\text { companies. }\end{array}$} & \multirow{2}{*}{$\begin{array}{l}\text { [Research } \\
\text { workshop] }\end{array}$} & & \\
\hline & & & \multirow{3}{*}{$\begin{array}{l}\text { Change of mind within the } \\
\text { company is needed to maintain } \\
\text { operational transition towards } \\
\text { DM implementation. }\end{array}$} & \multirow{3}{*}{ [68] } \\
\hline 32 & $\begin{array}{l}\text { Facilitated movement and re-location } \\
\text { of manufacturing facilities in case of } \\
\text { market or environmental changes. }\end{array}$ & [67] & & \\
\hline \multirow{2}{*}{33} & \multirow{2}{*}{$\begin{array}{l}\text { Worldwide manufacturing facilities } \\
\text { for maintenance and production of } \\
\text { spare parts. }\end{array}$} & \multirow{2}{*}{ [75] } & & \\
\hline & & & \multirow{2}{*}{$\begin{array}{l}\text { Limited independence of } \\
\text { companies caused by other } \\
\text { network units and their processes } \\
\text { and objectives. }\end{array}$} & \multirow[b]{2}{*}{ [70] } \\
\hline 34 & $\begin{array}{l}\text { Improved responsiveness, flexibility } \\
\text { and efficiency for the manufacturing } \\
\text { of spare parts. }\end{array}$ & [75] & & \\
\hline 35 & $\begin{array}{l}\text { Higher employment rate achieved by } \\
\text { supporting local producers who } \\
\text { employ local communities. }\end{array}$ & {$[12,68]$} & \multirow{2}{*}{$\begin{array}{l}\text { Challenges related to training of } \\
\text { employees. }\end{array}$} & \multirow[t]{2}{*}[12,68]{} \\
\hline 36 & $\begin{array}{l}\text { Support of local crafts and } \\
\text { craftsmanship. }\end{array}$ & $\begin{array}{c}\text { Expert } \\
\text { interviews] }\end{array}$ & & \\
\hline 37 & $\begin{array}{l}\text { Low capital cost of entry to } \\
\text { distributed network. }\end{array}$ & $\begin{array}{c}\text { [Expert } \\
\text { interviews] }\end{array}$ & \multirow{3}{*}{$\begin{array}{l}\text { Concerns of companies related to } \\
\text { processes fragmentation caused } \\
\text { by offshoring and outsourcing of } \\
\text { operations. }\end{array}$} & \multirow{3}{*}{ [78] } \\
\hline 38 & $\begin{array}{l}\text { A shift towards service-based } \\
\text { business models. }\end{array}$ & {$[20,78]$} & & \\
\hline 39 & $\begin{array}{l}\text { Opportunity for developing countries } \\
\text { to produce goods on their own } \\
\text { demand. }\end{array}$ & [71] & & \\
\hline
\end{tabular}


Table 3. Cont.

\begin{tabular}{|c|c|c|c|c|}
\hline No. & DM Opportunities & $\begin{array}{l}\text { Literature } \\
\text { Source }\end{array}$ & DM Challenges & $\begin{array}{l}\text { Literature } \\
\text { Source }\end{array}$ \\
\hline \multicolumn{5}{|c|}{ Customer-orientation: } \\
\hline 40 & $\begin{array}{l}\text { Small-scale manufacturing of only } \\
\text { products required by customers. }\end{array}$ & {$[12,67]$} & \multirow{3}{*}{$\begin{array}{l}\text { Reduced efficiency of } \\
\text { manufacturing processes } \\
\text { compared to centralised mass } \\
\text { production facilities. }\end{array}$} & \multirow{3}{*}{ [69] } \\
\hline 41 & $\begin{array}{l}\text { Resilience to changes in demand } \\
\text { caused by moving from centralised } \\
\text { production of single product to } \\
\text { small-scale production of } \\
\text { multi-products. }\end{array}$ & [67] & & \\
\hline 42 & $\begin{array}{l}\text { Reduced warehousing costs related to } \\
\text { unsold products, caused by } \\
\text { on-demand production. }\end{array}$ & [67] & & \\
\hline 43 & $\begin{array}{l}\text { Open-source innovations encouraged } \\
\text { by customer involvement in design } \\
\text { and production processes. }\end{array}$ & [12] & \multirow{2}{*}{$\begin{array}{l}\text { Lack of regulations increase risk } \\
\text { of illegal copying of objects } \\
\text { through access to digital files and } \\
\text { open-source information. }\end{array}$} & \multirow{2}{*}{ [78] } \\
\hline 44 & $\begin{array}{l}\text { Free open-source libraries from which } \\
\text { designs can be downloaded and } \\
\text { improved by everyone. }\end{array}$ & $\begin{array}{c}\text { [Expert } \\
\text { interviews] }\end{array}$ & & \\
\hline 45 & $\begin{array}{l}\text { Customer involvement in production } \\
\text { of personalised products. }\end{array}$ & {$[12,67,79]$} & \multirow{2}{*}{$\begin{array}{l}\text { A risk to move from consumption } \\
\text { of products to consumption of } \\
\text { production. }\end{array}$} & \multirow{2}{*}{$\begin{array}{l}\text { [Expert } \\
\text { interviews] }\end{array}$} \\
\hline \multirow{2}{*}{46} & \multirow[b]{2}{*}{$\begin{array}{l}\text { Customers able to use digital design } \\
\text { tools and send a production request to } \\
\text { local manufacturing facility. }\end{array}$} & \multirow{2}{*}{ [12] } & & \\
\hline & & & \multirow{2}{*}{$\begin{array}{l}\text { Challenges related to encouraging } \\
\text { customers to adopt the new } \\
\text { system of consuming and } \\
\text { producing. }\end{array}$} & \multirow[t]{2}{*}{$\begin{array}{l}\text { [Expert } \\
\text { interviews] }\end{array}$} \\
\hline \multirow{2}{*}{47} & \multirow{2}{*}{$\begin{array}{l}\text { Open-access workshops, which allow } \\
\text { users to get involved in product } \\
\text { development processes. }\end{array}$} & \multirow{2}{*}[12,69]{} & & \\
\hline & & & \multirow{2}{*}{$\begin{array}{l}\text { The choice of location of openly } \\
\text { accessible manufacturing facilities } \\
\text { must take into account the radius } \\
\text { in which people are reached. }\end{array}$} & \multirow[b]{2}{*}{ [71] } \\
\hline 48 & $\begin{array}{l}\text { New community-sharing places to } \\
\text { learn skills: repair cafes, makerspaces, } \\
\text { co-working spaces etc. }\end{array}$ & $\begin{array}{c}\text { [Expert } \\
\text { interviews] }\end{array}$ & & \\
\hline 49 & $\begin{array}{l}\text { Distribution of knowledge and share } \\
\text { of skills. }\end{array}$ & $\begin{array}{l}\text { [Expert } \\
\text { interviews, } \\
\text { Research } \\
\text { workshop] }\end{array}$ & \multirow{2}{*}{$\begin{array}{l}\text { Home and DIY production } \\
\text { distinguishes by limited } \\
\text { manpower, tools, skills and } \\
\text { investment capacity. }\end{array}$} & \multirow[t]{2}{*}{ [80] } \\
\hline \multirow[t]{2}{*}{50} & \multirow{2}{*}{$\begin{array}{l}\text { Education of consumers, which } \\
\text { provides a better understanding of } \\
\text { production and efficient use of } \\
\text { products. }\end{array}$} & \multirow[t]{2}{*}{ [12] } & & \\
\hline & & & $\begin{array}{l}\text { Not all parts of products are } \\
\text { suitable for DIY manufacturing. }\end{array}$ & [80] \\
\hline 51 & $\begin{array}{l}\text { Personalised services supporting } \\
\text { personalised products. }\end{array}$ & [11] & \multirow{3}{*}{$\begin{array}{l}\text { Higher cost of personalised/ } \\
\text { bespoke products and services } \\
\text { compared to traditionally mass } \\
\text { manufactured equivalent. }\end{array}$} & \multirow{3}{*}{ [12] } \\
\hline 52 & $\begin{array}{l}\text { Facilitated companies enter to niche } \\
\text { markets. }\end{array}$ & [67] & & \\
\hline \multirow{2}{*}{53} & & \multirow{2}{*}{ [12] } & & \\
\hline & $\begin{array}{l}\text { Mass customisation and cost-effective } \\
\text { bespoke production. }\end{array}$ & & $\begin{array}{l}\text { Potential conflicts within } \\
\text { organisations caused by choices to } \\
\text { offer standardised, personalised, } \\
\text { inclusive or bespoke products. }\end{array}$ & [12] \\
\hline 54 & $\begin{array}{l}\text { Long-lasting companies' relationship } \\
\text { with customers, caused by proximity } \\
\text { use of digital technologies. }\end{array}$ & [12] & \multirow{2}{*}{$\begin{array}{l}\text { Concerns of privacy issues of } \\
\text { companies' data caused by } \\
\text { application of cloud } \\
\text { manufacturing and ICT. }\end{array}$} & \multirow[t]{2}{*}{ [12] } \\
\hline 55 & $\begin{array}{l}\text { Facilitated collaboration between } \\
\text { producer and customer. }\end{array}$ & $\begin{array}{l}\text { [Research } \\
\text { workshop] }\end{array}$ & & \\
\hline
\end{tabular}

3.3. Prescriptive Study I (PS-I): Development of PSS+DM Near-Future Scenarios and the PSS+DM Design Tool Version 1.0

This section describes how findings from the two previous research stages were applied to develop a PSS design support, i.e., a design tool for DM-enabled PSS implementation. According to the Design 
Research Methodology (DRM) [26], this support does not evolve directly from the RC and DS-I stages, and creativity and imagination must be applied to develop a successful design tool. Four stages, based on the DRM, were used to create the PSS+DM Design Tool: (1) problem identification (collection of PSS implementation barriers); (2) development of initial concept (PSS+DM near-future scenarios); (3) creation of a tangible form of a concept (Scenario Cards); and (4) detailing of the tangible artefacts for its practical use (Scenario Cards mapped on the Innovation Diagram, with use guidelines). It is important to highlight that the Design Tool building process requires iterations within and between stages [26]. Below, the creative process for the development of the PSS+DM near-future scenarios and their integration into the PSS+DM Design Tool is presented.

\subsubsection{PSS+DM Near-Future Scenarios}

Forty-eight PSS implementation barriers and 55 DM opportunities (with related challenges) were used to develop PSS+DM near-future scenarios. In the context of this paper, near-future scenarios are meant as brief descriptions of possible future events that aim to facilitate present decision making [87]. For the scenario development, a theory building approach [27] was applied aiming to explore the relationship between PSS and DM and develop new insights by matching all PSS implementation barriers with DM opportunities and challenges. This process was facilitated by applying the cognitive mapping method [28] which is based on the physical interaction with data aiming to map opportunities, trends, and challenges (DM opportunities and challenges) between present issues (PSS barriers) and desirable futures (PSS+DM near-future scenarios) (Figure 1). In this way, each identified PSS barrier was systematically coupled with each individual DM opportunity in all possible combinations to understand if the latter could tackle the former. The authors assessed initial pairings aiming to identify and validate the logical pairings which were described in short scenarios narrating specific DM features and their application for PSS implementation, with multiple scenarios addressing individual barriers. It is important to mention that 35 out of 48 collected PSS barriers were addressed in scenarios. The remaining could not be addressed because DM opportunities were not able to tackle them. As a result, the first set of 35 PSS+DM near-future scenarios were built to address each PSS lifecycle stage, where categorisation was adopted from Lelah et al. [87] and Aurich et al. [88], thus illustrating the potential support to sustainable PSS implementation. The scenarios were evaluated after the integration in the PSS+DM Design Tool and their number changed after each iteration. The following text briefly describes DM contribution to each PSS lifecycle stage including sustainability implications of the PSS and DM combination. The complete list of 40 scenarios included in the final version of the PSS+DM Design Tool is provided in Appendix A of this paper.

PSS Design stage predominantly benefits from the collaboration between the PSS provider and customer, enabled by connectivity through digital channels and physical interaction in local manufacturing facilities. This collaboration allows customers to get involved in PSS design processes and specify requirements for products and services, enabling PSS providers to offer only those products and services that are required by customers, improving economic and environmental sustainability. AM provides PSS companies with design specifications for PSS products. Production using AM machinery allows to reduce the number and amount of materials, simplify components for easy disassembly, re-manufacturing, and upgrade, as well as reduce waste production during the manufacturing stage, as a result making PSS products and their maintenance more environmentally sustainable. Sensors applied to existing product-oriented offerings can show customer consumption patterns and lifecycle costing and help improve the design of future PSS. PSS Design stage includes 16 near-future scenarios. 


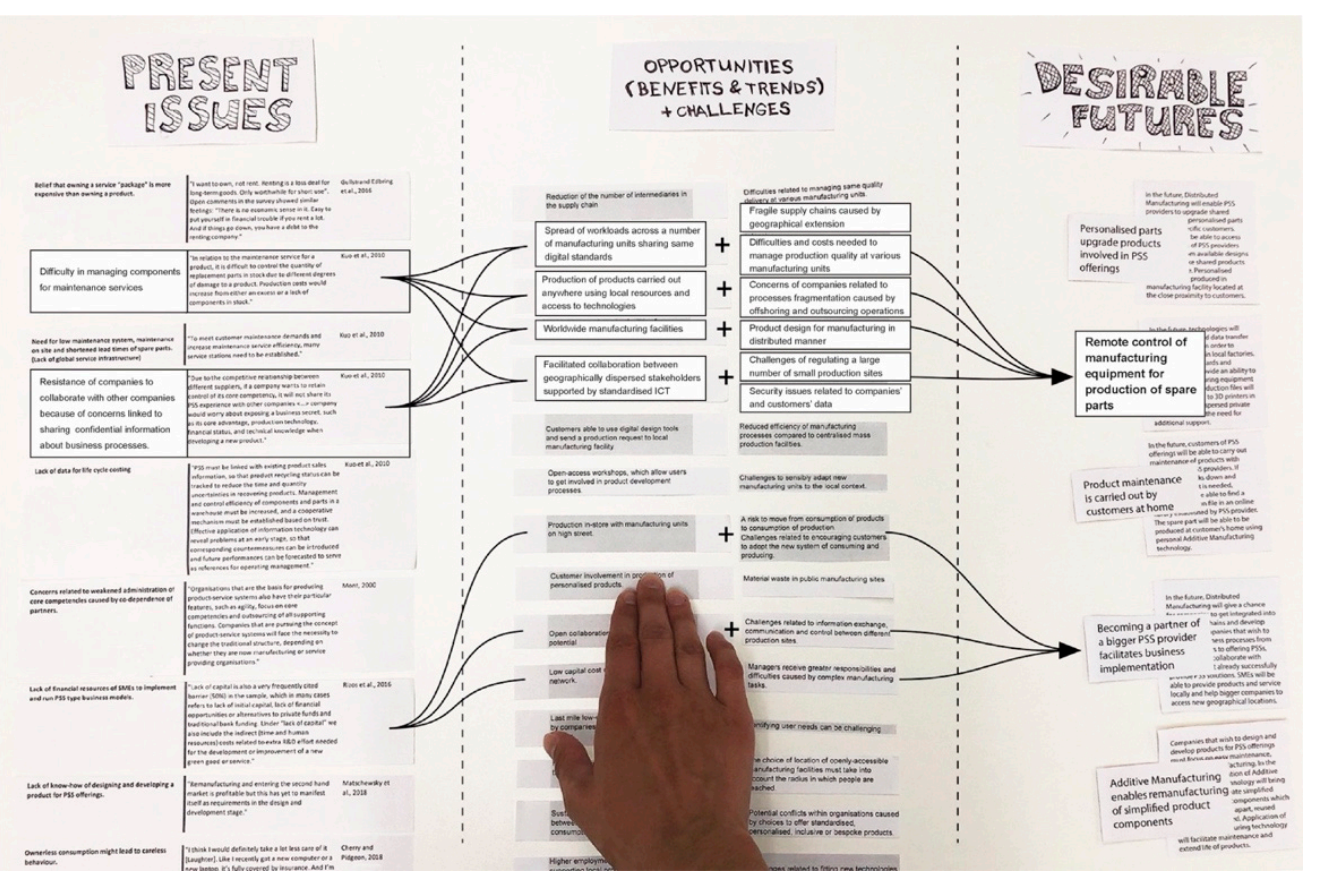

Figure 1. Cognitive mapping method applied to PSS+DM near-future scenario development.

Material Production and Manufacturing for PSS stage benefits from distribution of manufacturing facilities equipped with digitally connected manufacturing technologies. An ability to send digital production files to remote locations allows PSS companies to produce products at a close proximity to customers and/or resources, at the same time improving environmental sustainability through reduced delivery distances. Advancement of makerspaces, manufacturing facilities in public spaces and home-workshops enables customer-run manufacturing. This transformation towards a customer-oriented value proposition helps PSS companies build stronger relationships with the end-customers. Furthermore, localisation of manufacturing facilities enables PSS providers to collaborate with local SMEs and start-ups, support local producers and communities, potentially improving economic and social sustainability. This PSS lifecycle stage is supported by 19 near-future scenarios.

Use of PSS stage benefits considerably from the customer-orientation feature of DM, with PSS companies supporting their customers with knowledge needed to maintain PSS products, addressing social and environmental sustainability. The community of knowledgeable customers is able to identify product damage, contact PSS companies, or provide required services themselves, prolonging life of PSS products. Rapid service provision can be attained due to access to local manufacturing facilities, such as makerspaces or home-workshops. Sensors mounted on PSS products provide feedback about product damage or any need of maintenance, reducing manufacturer's costs and preventing PSS product from going to landfill. AM can optimise (and localise) production of spare parts by reducing the time and resources needed to support PSS offerings. Use of PSS stage includes 25 near-future scenarios.

PSS End-of-Life phase is facilitated by the application of sensor technology, which helps indicate products' end-of-life by alerting PSS providers and customers. Improved PSS design through the application of AM technologies facilitates disassemble, re-manufacturing, and recycling of PSS products, thus promoting closed-loop PSS implementation. Even though recycling is considered as the last chance to retrieve materials and energy embedded in products included in PSS, a network of localised recycling facilities eases product collection, recycling and re-manufacturing. Seven near-future scenarios are aligned with this stage.

The following sections describe how the PSS+DM near-future scenarios have been integrated into the Design Tool. 


\subsubsection{PSS+DM Design Tool Version 1.0}

The aim of the PSS+DM Design Tool is to facilitate companies and design practitioners in considering potential DM applications in each PSS lifecycle stage in order to improve PSS implementation. The tool is designed to achieve the following goals: (1) to provide knowledge about potential DM opportunities; (2) to encourage its users to innovate in each PSS lifecycle stage; and (3) to stimulate creative future-oriented thinking. Since DM is partially enabled by technologies which evolve and develop rapidly, it is important to encourage tool users to think about the near future, so ideas developed using the tool do not get obsolete before they are realised. In addition, based on the study by Chiu [89], future orientation improves users' creative imagination, thus improving idea generation.

\section{Tool Elements}

The first version of the PSS+DM Design Tool comprises 35 Scenario Cards and the Innovation Diagram. The way Scenario Cards were built was inspired by the analysis of the communication elements used in nine reports presenting future scenarios [90-98]. Each of the double-sided Scenario Cards consists of a title and a short scenario description, its illustration, colour coding and icons (for scenario positioning on the Innovation Diagram), a summary of challenges and benefits, and a question triggering idea generation, which was made by simply asking how the key DM feature of the scenario can help support PSS implementation (Figure 2).
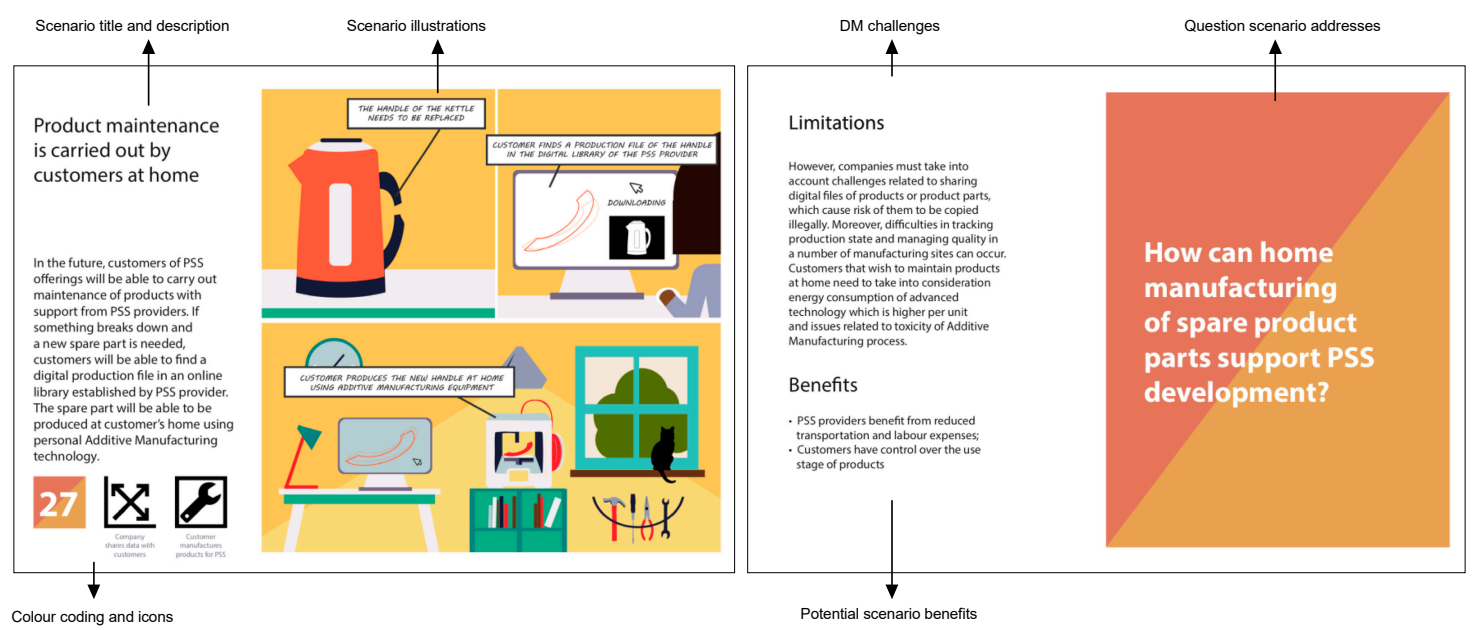

Figure 2. The front and back sides of one of the PSS+DM near-future Scenario Cards.

In order to make Scenario Cards effective in triggering idea generation, categorisation is crucial. Based on the Design Oriented Scenarios framework by Manzini and Jégou [99] and the diagram developed by Emili et al. [100], all 35 Scenario Cards were organised around polarities on the Innovation Diagram (Figure 3), created as a representation of key dimensions of PSS and DM which can be addressed by the scenarios. The Innovation Diagram serves as (1) a framework to categorise and position all Scenario Cards and facilitate their selection process, and (2) a map for placing ideas generated during the design process. The Innovation Diagram, made of two polarities, combines PSS and DM features. The horizontal axis visualises six PSS lifecycle stages: Design, Business Implementation, Material production and Manufacturing, Distribution, Use and End-of-life. The vertical axis focuses on the level of customer involvement. Customer involvement can be categorised in five levels: Customer only uses PSS offerings, Customer chooses from PSS offerings, Customer monitors PSS offerings, Customer designs PSS offerings and Customer manufactures products/components for PSS offerings. Manufacturing companies can contribute to the democratisation of manufacturing and enable customer involvement. For this reason, the level of company's openness is also included in the Innovation 
Diagram. This describes with whom the company shares open production files of products or product components and instructions on how these products or their components must be produced. Four levels of openness have been identified: Company does not share data, Company shares data with other manufacturing facilities, Company shares data with customers, and Company shares data open source. To summarise, the Innovation Diagram with mapped Scenario Cards consists of two polarities, the company's openness icons, a complete list of scenarios and numbers, and icons and colour coding representing the position of each scenario (Figure 2). The same Diagram, without Scenario Cards mapped on it, has been created to be used for placing Post-It notes during idea generation sessions (Figure 4).

Use of the Tool

The tool can be used in multiple ways. Users who wish to transform existing business processes towards offering PSS solutions should start from reading all Scenario Cards from each lifecycle stage, starting from PSS Design and moving towards the End-of-Life. Users already offering PSS solutions or having previous PSS implementation experience can start using the tool from reading Scenario Cards from a specific lifecycle stage they wish to improve. Users who do not have a specific goal and are open to innovations can start from selecting Cards from any lifecycle stage, different levels of customer involvement, or company's openness. In either case, ideas triggered by the Scenario Cards can be written down on Post-It notes and placed on the empty Innovation Diagram (Figure 4).

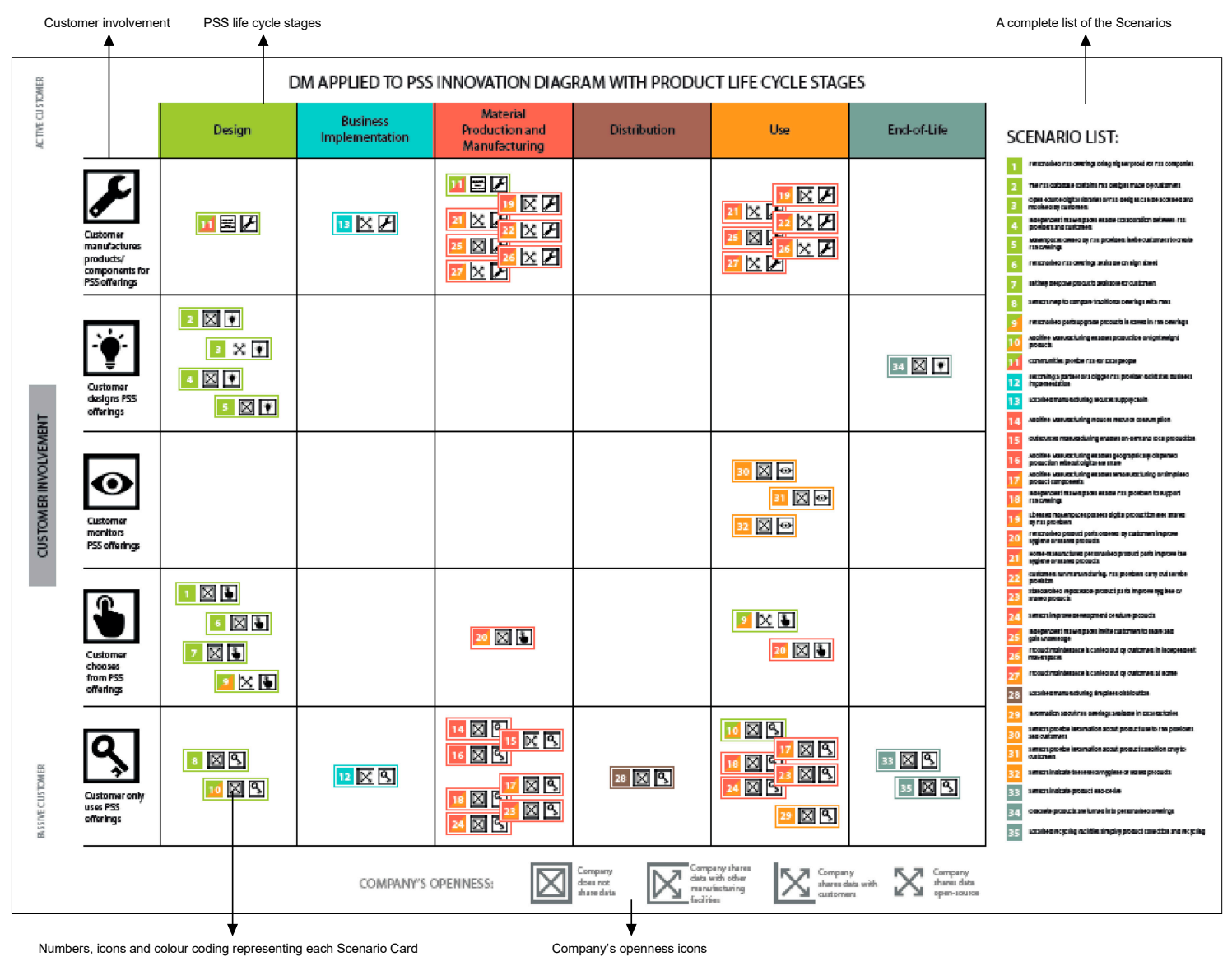

Figure 3. PSS+DM Innovation Diagram. 


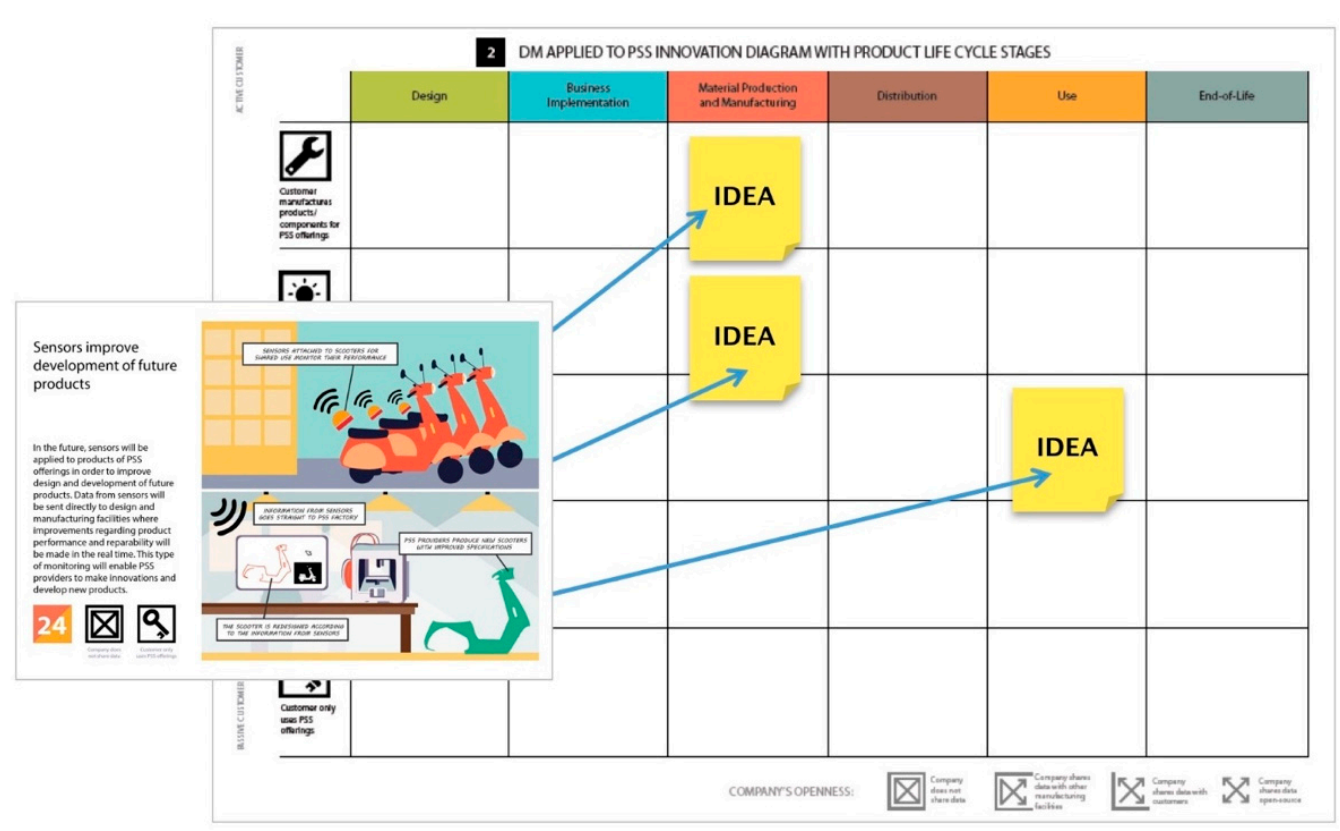

Figure 4. PSS+DM idea generation on the Innovation Diagram.

\subsection{Descriptive Study II (DS-II): Empirical Testing of the PSS+DM Design Tool Version 1.0}

The aim of the testing was to evaluate how effective and usable the first version of the PSS+DM Design Tool is during a practical idea generation process. The Tool was tested during an 8-h workshop with 45 students from design-related backgrounds: product design, design management and PSS design. The workshop was a part of a two-week pilot course focused on designing a lighting solution combining PSS and DM principles. Students were introduced to PSS and DM concepts and asked to develop initial PSS lighting ideas prior to applying the PSS+DM Design Tool. Working in groups (made of five students), students had $1 \mathrm{~h}$ to familiarise themselves with the tool's contents, $4 \mathrm{~h}$ to generate ideas and place them on the Innovation Diagram, and $3 \mathrm{~h}$ for selecting final ideas to be integrated into their initial PSS concepts. Despite the fact that the testing with students helped identify strengths and weaknesses of the first version of the PSS+DM Design Tool, there are biases and limitations to take into consideration. When providing feedback, students were reacting mostly positively to the tool, making it challenging for the authors to identify whether it was their genuine opinion. However, this bias has been addressed by applying data triangulation and selecting multiple data collection methods: questionnaires, for collecting qualitative and quantitative feedback about effectiveness and usability of the Tool; verbal feedbacks describing how the tool was approached and used; qualitative and quantitative analysis of ideas generated and ideas incorporated into final concepts; and authors' observations on behaviours and design dynamics during the workshop. Moreover, the majority of the students were not native English speakers and faced some difficulties in understanding the contents of the Scenario Cards. This required continued support from the authors facilitating the workshop. The findings of the first empirical testing are summarised in the following paragraphs.

\subsubsection{Effectiveness}

Evaluation of effectiveness of the PSS+DM Design Tool aimed at (1) demonstrating how well the tool can support initial idea generation and their integration into final PSS concept, and (2) understanding potential benefits of DM application. This was assessed through the questionnaires and the collected initial and final ideas generated using the tool.

Initial idea generation and integration into final PSS solutions. During the workshop, students analysed Scenario Cards and generated ideas for PSS lighting solutions, recorded them on Post-It notes, and placed them on the Innovation Diagram. Later, students were asked to select promising 
ideas to be integrated into their final PSS solutions. Quantitatively, students (working in 10 groups), generated an average of 20 ideas per group and chose nine of them to incorporate into their final PSS solutions. Three percent of all initial ideas were irrelevant to the design brief, $56 \%$ were identified as generic (i.e., ideas that simply replicated the insights presented in the scenarios), and $41 \%$ of ideas were specific (i.e., ideas that creatively re-elaborated insights presented in the scenarios to develop PSS solutions not described in the scenarios). Qualitatively, the contents of initial ideas (examples taken from one group) varied between being copied from descriptions of the Scenario Cards (generic ideas): "Entrepreneur receives data from sensors and customer feedback to improve PSS offerings." and addressing specific PSS concepts: "Entrepreneur receives design specs to build light-providing drone for miners." However, ideas incorporated into final concepts of the same group were more elaborated: "Local entrepreneur builds the drones providing light to miners within guidelines utilising local materials and makerspaces. Field worker requests drones per period of use, while usage data is shared with entrepreneur." Innovation Diagrams filled with Post-It notes show that initial ideas covered a complete PSS lifecycle and all levels of customer involvement (Figure 5). Moreover, the majority of the groups presented their final ideas along the lifecycle of their PSS solutions, proving the effectiveness of the tool to support lifecycle-oriented thinking.

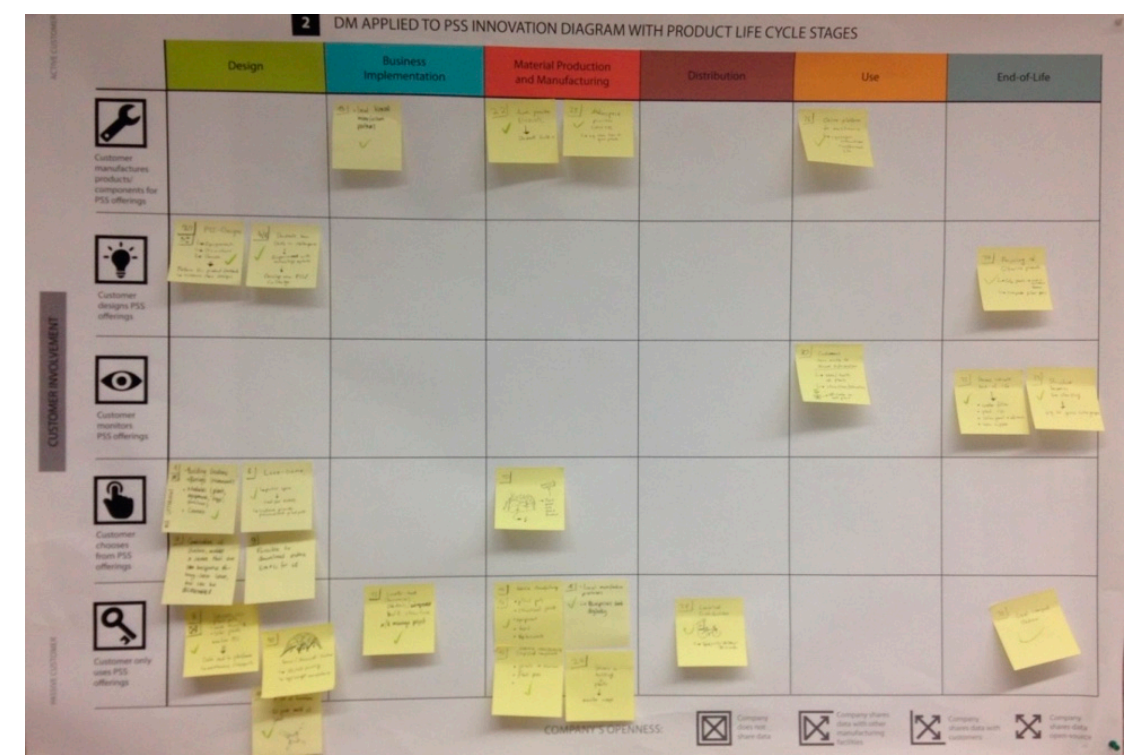

Figure 5. Innovation Diagram with initial students' ideas.

Understanding potential benefits of DM. Analysis of initial and final ideas shows that the tool helped students grasp potential benefits of DM. Firstly, various levels of customer involvement and companies' openness were described in students' ideas: "Our company will educate users how to maintain and repair solar panels" (company shares data with customers and enables them to manufacture components); "Provider is able to operate customers' $3 D$ printers to print parts remotely without sharing digital 3D model files of those parts to the customer" (customer only uses PSS offerings while company does not share data). Secondly, initial and final ideas developed by students included aspects of the three key DM features, proving that they were able to understand them from the Scenario Cards: application of digital and physical technologies ("Monitor each activity, monitor accuracy, share data with friends and family"), localisation ("Cooperation with local bamboo processing plant") and customer-orientation ("We will educate users how to maintain/repair solar panels"). Summary of the questionnaire results in Table 4 shows that the highest evaluation points were given to the Scenario Cards featured to facilitate understanding of potential benefits of DM. The same evaluation was given to the Innovation Diagram as a helpful idea generation tool. However, improvements must be made to the Scenario Cards in order to better stimulate group discussion, as this feature received the lowest evaluation point. 
Table 4. Feedback collected to evaluate effectiveness and usability of the first version of the PSS+DM Design Tool.

\begin{tabular}{|c|c|c|c|c|c|c|c|}
\hline \multicolumn{8}{|c|}{ Scenario Cards } \\
\hline & \multirow{2}{*}{ Question } & \multicolumn{6}{|c|}{$\begin{array}{l}\text { Evaluation } \\
\end{array}$} \\
\hline & & $\begin{array}{l}1 \text { Very } \\
\text { Poor }\end{array}$ & $\begin{array}{c}2 \\
\text { Poor }\end{array}$ & $\begin{array}{c}3 \\
\text { Sufficient }\end{array}$ & $\begin{array}{c}4 \\
\text { Good }\end{array}$ & $\begin{array}{c}5 \\
\text { Excellent }\end{array}$ & Average \\
\hline \multirow{3}{*}{ 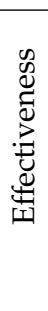 } & $\begin{array}{l}\text { 1. To what extent the Scenario Cards } \\
\text { helped you understand the potential } \\
\text { benefits of DM applied to PSS? }\end{array}$ & $0 \%$ & $0 \%$ & $7 \%$ & $53 \%$ & $40 \%$ & 4.3 \\
\hline & $\begin{array}{l}\text { 2. To what extent are the Scenario } \\
\text { Cards useful to generate ideas? }\end{array}$ & $0 \%$ & $2 \%$ & $15 \%$ & $41 \%$ & $42 \%$ & 4.2 \\
\hline & $\begin{array}{l}\text { 3. To what extent the Scenario Cards } \\
\text { helped you stimulate the discussion } \\
\text { in your group? }\end{array}$ & $0 \%$ & $2 \%$ & $12 \%$ & $61 \%$ & $25 \%$ & 4 \\
\hline \multirow{5}{*}{ 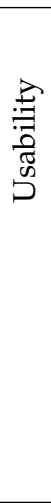 } & $\begin{array}{l}\text { 4. To what extent are the illustrations } \\
\text { on the Scenario Cards easy to } \\
\text { understand? }\end{array}$ & $0 \%$ & $0 \%$ & $11 \%$ & $55 \%$ & $34 \%$ & 4.2 \\
\hline & $\begin{array}{l}\text { 5. To what extent are the descriptions } \\
\text { of the scenarios easy to understand? }\end{array}$ & $0 \%$ & $4 \%$ & $30 \%$ & $54 \%$ & $12 \%$ & 3.7 \\
\hline & $\begin{array}{l}\text { 6. To what extent are the colour } \\
\text { coding and the icons easy to } \\
\text { understand? }\end{array}$ & $0 \%$ & $0 \%$ & $19 \%$ & $35 \%$ & $47 \%$ & 4.3 \\
\hline & $\begin{array}{l}\text { 7. To what extent, in general, is the } \\
\text { layout of the Scenario Cards relevant } \\
\text { to its contents? }\end{array}$ & $0 \%$ & $0 \%$ & $14 \%$ & $52 \%$ & $33 \%$ & 4.2 \\
\hline & $\begin{array}{l}\text { 8. To what extent are the Scenario } \\
\text { Cards easy to use? }\end{array}$ & $0 \%$ & $0 \%$ & $19 \%$ & $60 \%$ & $21 \%$ & 4 \\
\hline \multicolumn{8}{|c|}{ Innovation Diagram } \\
\hline & \multirow{2}{*}{ Question } & \multicolumn{6}{|c|}{ Evaluation } \\
\hline & & $\begin{array}{l}1 \text { Very } \\
\text { Poor }\end{array}$ & $\begin{array}{c}2 \\
\text { Poor }\end{array}$ & $\begin{array}{c}3 \\
\text { Sufficient }\end{array}$ & $\begin{array}{c}4 \\
\text { Good }\end{array}$ & $\begin{array}{c}5 \\
\text { Excellent }\end{array}$ & Average \\
\hline \multirow{3}{*}{ 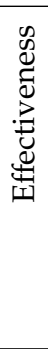 } & $\begin{array}{l}\text { 1. To what extent is the Innovation } \\
\text { Diagram useful to generate ideas? }\end{array}$ & $0 \%$ & $0 \%$ & $12 \%$ & $50 \%$ & $38 \%$ & 4.3 \\
\hline & $\begin{array}{l}\text { 2. To what extent has the Innovation } \\
\text { Diagram helped you take into } \\
\text { account a complete lifecycle of your } \\
\text { concept? }\end{array}$ & $0 \%$ & $2 \%$ & $17 \%$ & $41 \%$ & $41 \%$ & 4.2 \\
\hline & $\begin{array}{l}\text { 3. To what extent the Innovation } \\
\text { Diagram helped you stimulate the } \\
\text { discussion in your group? }\end{array}$ & $0 \%$ & $5 \%$ & $42 \%$ & $39 \%$ & $42 \%$ & 4.2 \\
\hline \multirow{2}{*}{ 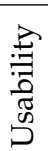 } & $\begin{array}{l}\text { 4. To what extent is the Innovation } \\
\text { Diagram easy to understand? }\end{array}$ & $0 \%$ & $0 \%$ & $17 \%$ & $71 \%$ & $2 \%$ & 4 \\
\hline & $\begin{array}{l}\text { 5. To what extent is the Innovation } \\
\text { Diagram easy to use? }\end{array}$ & $0 \%$ & $0 \%$ & $2 \%$ & $61 \%$ & $37 \%$ & 4.3 \\
\hline
\end{tabular}

\subsubsection{Usability}

Evaluation of the tool's usability aimed at (1) analysing how workshop participants approached the tool and (2) assessing the layouts of the Scenario Cards and the Innovation Diagram. This was evaluated through questionnaires, as well as verbal feedback collected from the participants about their experience using the tool and authors' observations carried out through the entire workshop.

Students were able to find their own way to approach the tool, starting from reading all the Scenario Cards or from focusing on a particular PSS lifecycle stage. Verbal feedback from workshop participants and authors' observations showed that the majority of groups firstly analysed all of the Scenario Cards and later started generating ideas for each lifecycle stage, starting from the PSS Design. Only one group started their idea generation process from analysing the Innovation Diagram ("We jumped from one stage to another, one stage triggered ideas for another stage."). This shows that the Innovation 
Diagram can be approached and used in multiple ways. Furthermore, this observation confirms the ability of the Diagram to support lifecycle-oriented thinking.

In terms of the layouts, scenario illustrations were identified as inspiring and engaging ("Very easy to understand, very visual"). It was highlighted by students that the layout of the Innovation Diagram helped them consider a complete PSS lifecycle ("It teases our thinking of the overall lifecycle, it reminded us about end-of-life, which we usually forget). However, some students found the Diagram difficult to understand because of the polarities and the amount of provided icons ("If we can understand the relationship between customer involvement and PSS lifecycle with ease it will be better"). Summary of the questionnaire results in Table 4 shows that the Innovation Diagram was identified as easy to use. Students also found colour coding and icons on the Scenario Cards easy to understand and gave them the highest evaluation points. Low evaluation points given to scenario descriptions can potentially be a result of a language barrier.

\subsection{Prescriptive Study II (PS-II): Development of the PSS+DM Design Tool Version 2.0}

\subsubsection{Insights from the First Empirical Testing}

Data collected during the first empirical testing of the PSS+DM Design Tool version 1.0 were analysed in order to identify successful tool characteristics and features to be improved.

Scenario Cards. The variety and depth of the initial and final ideas generated during the workshop show that the Scenario Cards helped the students get familiar with DM features, understand their potential opportunities, and incorporate them into initial PSS concepts. Judging from the students' verbal feedback and authors' observations, the way the DM model was presented aroused students' interest and initiated discussions. In terms of the layout, illustrations and scenario narratives facilitated rapid understanding of each Scenario Card. However, the study shows that the Scenario Cards were missing a more detailed explanation of DM features and their technological aspects, including DM industrial case studies. Finally, it emerged that more questions provided on the Cards were needed to better facilitate idea generation process.

Innovation Diagram. The Innovation Diagram aimed at supporting its users in considering the complete PSS lifecycle and different levels of customer involvement in various lifecycle stages. The initial ideas generated by students and mapped on the Innovation Diagrams show that workshop participants considered each lifecycle stage of their PSS concepts. This has been also proved through the verbal feedback. However, some participants highlighted that there was a lack of guidelines provided on how to start and finish the idea generation process and how to integrate initial ideas into final PSS solutions. Customer involvement and company's openness aspects were identified as confusing and difficult to comprehend. It can be summarised that the Innovation Diagram supports PSS lifecycle-oriented thinking, meaning that the polarity made of the PSS lifecycle stages encourages users to consider a complete PSS lifecycle, thus potentially generating ideas for sustainable PSS offerings. However, the axis presenting DM features requires further improvements.

The first empirical testing shows that the tool partially achieved its goals: (1) it has provided workshop participants with knowledge about potential DM benefits; (2) it has encouraged them to innovate different PSS lifecycle stages; and, to some extent, (3) it has stimulated creative future-oriented thinking. Moreover, the first practical application proved that the first version of the PSS+DM Design Tool requires further improvements in order to better support design of PSS offerings along their lifecycle stages. Forty-five students provided their individual feedback using open-ended questions in questionnaires. This feedback was analysed aiming to identify strengths and weaknesses of the tool and to summarise suggestions for new features to be integrated in the updated version of the tool. This information was analysed and clustered into four recommendations summarised in Table 5. 
Table 5. Recommendations for new features for the updated version of the PSS+DM Design Tool.

\begin{tabular}{|c|c|c|c|c|}
\hline \multicolumn{5}{|c|}{ Scenario Cards } \\
\hline & Worked & Did Not Work & $\begin{array}{c}\text { Examples of Suggestions } \\
\text { from Participants }\end{array}$ & $\begin{array}{l}\text { Recommendations for } \\
\text { New Features }\end{array}$ \\
\hline 离 & \multirow{2}{*}{$\begin{array}{l}\text { 1. Overall DM } \\
\text { concept and the } \\
\text { way it was } \\
\text { presented aroused } \\
\text { students' interest. } \\
\text { 2. Illustrations } \\
\text { were easy to } \\
\text { understand and } \\
\text { inspiring. }\end{array}$} & $\begin{array}{l}\text { 1. Some students } \\
\text { had difficulties } \\
\text { with applying } \\
\text { scenarios to their } \\
\text { own PSS concepts. }\end{array}$ & $\begin{array}{l}\text { "Give more questions to } \\
\text { inspire us." }\end{array}$ & $\begin{array}{l}\text { 1. Provide more questions } \\
\text { in each Scenario Card to } \\
\text { trigger idea generation. }\end{array}$ \\
\hline 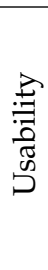 & & $\begin{array}{l}\text { 2. DM features } \\
\text { were missing more } \\
\text { detailed } \\
\text { explanations about } \\
\text { technological } \\
\text { features and } \\
\text { real-world cases. }\end{array}$ & $\begin{array}{l}\text { "A good case study as an } \\
\text { example could help us to } \\
\text { better understand DM } \\
\text { concept" } \\
\text { "More in-depth information } \\
\text { about the technologies." }\end{array}$ & $\begin{array}{l}\text { 2. Include case studies to } \\
\text { better illustrate DM } \\
\text { potential and provide } \\
\text { descriptions of advanced } \\
\text { technological features. }\end{array}$ \\
\hline \multicolumn{5}{|c|}{$\begin{array}{l}\text { Innovation Diagram } \\
\end{array}$} \\
\hline & Worked & Did Not Work & $\begin{array}{c}\text { Examples of Suggestions } \\
\text { from Participants }\end{array}$ & $\begin{array}{l}\text { Recommendations for } \\
\text { New Features }\end{array}$ \\
\hline 离 & \multirow{2}{*}{$\begin{array}{l}\text { 1. Focus on a } \\
\text { complete PSS } \\
\text { lifecycle. }\end{array}$} & $\begin{array}{l}\text { 3. Lack of } \\
\text { guidelines about } \\
\text { where to start and } \\
\text { finish the idea } \\
\text { generation process. }\end{array}$ & $\begin{array}{l}\text { "If the diagram could have } \\
\text { more rules and activities it } \\
\text { will be better." } \\
\text { "Beginning at random stages } \\
\text { of lifecycle - starting at end } \\
\text { of life might change the final } \\
\text { design - order can matter." }\end{array}$ & $\begin{array}{l}\text { 3. Provide more specific } \\
\text { step-by-step guidelines of } \\
\text { the tool application } \\
\text { process, particularly } \\
\text { emphasizing how to start } \\
\text { and finish. }\end{array}$ \\
\hline 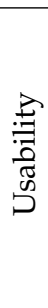 & & $\begin{array}{l}\text { 4. Confusion } \\
\text { linked to two } \\
\text { different DM } \\
\text { categorisation: } \\
\text { customer } \\
\text { involvement and } \\
\text { company's } \\
\text { openness. }\end{array}$ & $\begin{array}{l}\text { "It is not easy to map on the } \\
\text { diagram. [Customer } \\
\text { involvement icons] need to be } \\
\text { simplified or re-categorized } \\
\text { and help user to understand } \\
\text { the contents easier." }\end{array}$ & $\begin{array}{l}\text { 4. Simplify the Diagram, } \\
\text { keeping PSS lifecycle } \\
\text { stages and removing } \\
\text { Customer Involvement } \\
\text { and Company's Openness, } \\
\text { potentially replacing them } \\
\text { by a different axis. }\end{array}$ \\
\hline
\end{tabular}

\subsubsection{Design of the PSS+DM Design Tool Version 2.0}

The tool design has been revised and updated according to the findings from the first empirical testing. Four recommendations for new features (Table 5) were integrated to the second version of the PSS+DM Design Tool.

Scenario Cards. Since the study participants identified DM as an unfamiliar topic, the Cards were updated to better present DM features. Firstly, each Scenario Card was illustrated with a DM case study, introducing a real-world example of a particular DM feature. Secondly, more scenarios describing applications of advanced technologies (e.g., 4D printing, 3D scanning, AM, etc.) were added. For this reason, the number of Scenario Cards increased to 44. Finally, more questions to trigger idea generation were provided on the back of each Card. The aim of additional questions was to encourage users to think of particular DM features addressed in the scenario: localisation (Where?), customer-orientation (Who?), and application of technologies (What/How?). Addressed PSS implementation barriers, PSS lifecycle stages and DM features were placed on the front side of the card. The information was broken up using bullet points and images illustrating DM case studies were added, making cards easier to read for non-native English speakers. An example of both sides of the updated Scenario Card is presented in Figure 6. 


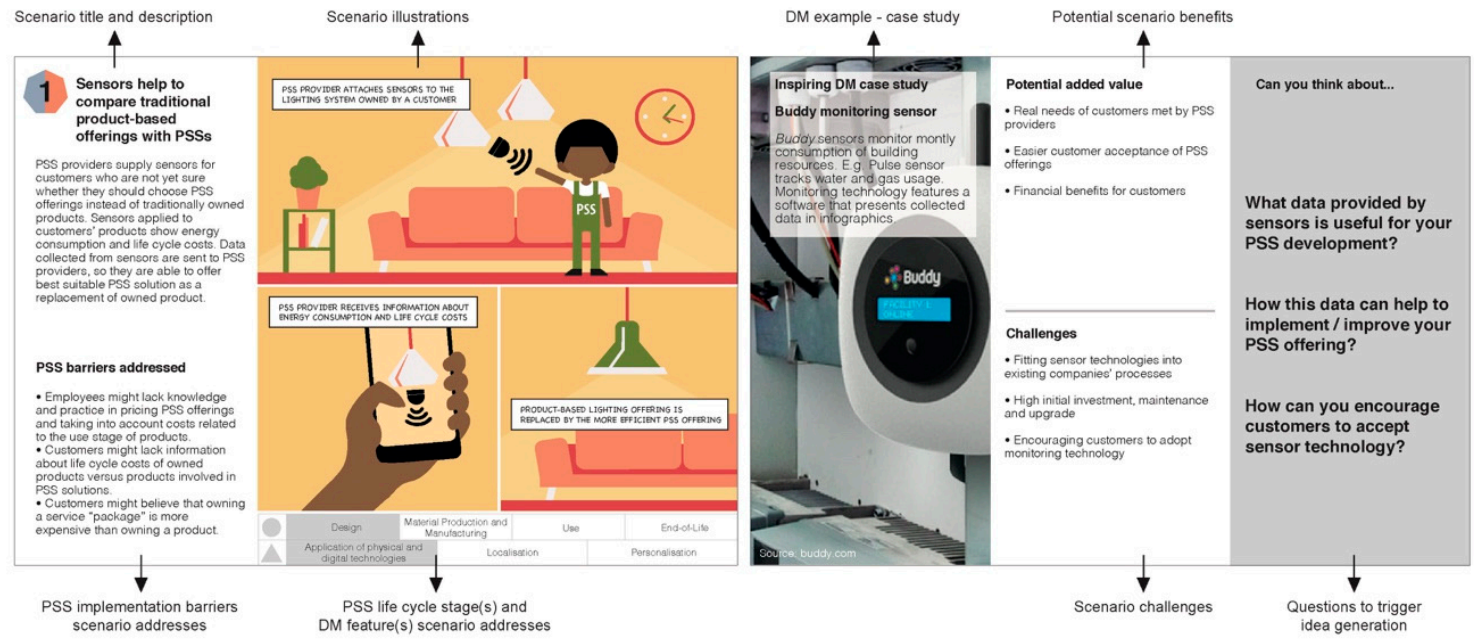

Figure 6. The front and back sides of one of the PSS+DM Scenario Cards version 2.0.

Innovation Diagram. Customer Involvement and Company's Openness, elements identified as confusing and difficult to comprehend, were removed from the Innovation Diagram. In the updated version of the tool, the vertical axis of the Diagram represents the three key DM features: application of digital and physical technologies, localisation and personalisation (customer-orientation) (Figure 7). All Scenario Cards have been mapped on this diagram to facilitate the relevant card selection process.
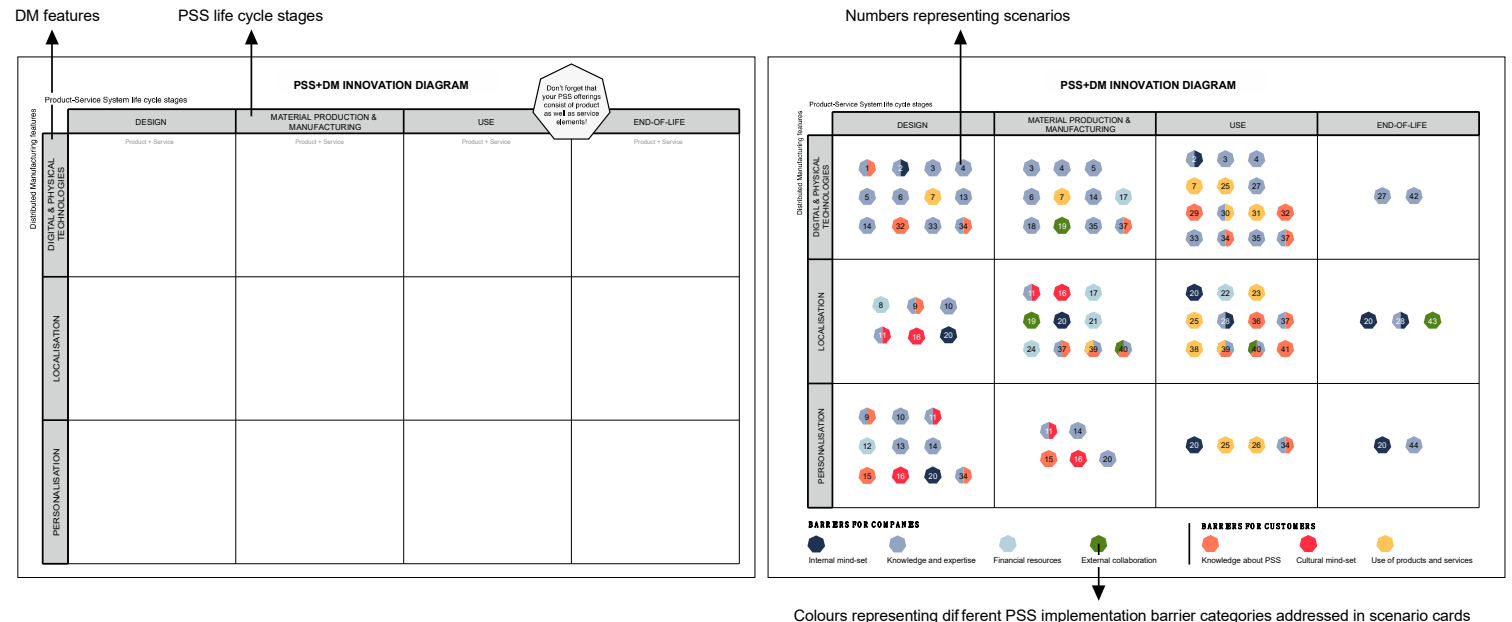

Figure 7. PSS+DM Innovation Diagram version 2.0: for idea generation and with Scenario Cards mapped on it.

\subsection{Descriptive Study III (DS-III): Empirical Testing of the PSS+DM Design Tool Version 2.0}

The second empirical testing aimed at evaluating the tool against three criteria: completeness, effectiveness, and usability. The completeness aspect, which has not been tested with students previously, was introduced to gather insights from experts and professionals from companies and design agencies about the contents of the tool. Data were collected through interviews (from experts), questionnaires, and the authors' observations (from participants from companies and design agencies).

\subsubsection{Testing with Experts from PSS- and/or DM-Related Fields}

The first testing of the second version of the PSS+DM Design Tool was conducted with 10 participants: three experts from DM-related fields, two experts from PSS-related fields, and five experts 
with competences on both DM and PSS. Six participants were academics (educators and researchers) and four of them were industry professionals. Three experts already took part in the Descriptive Study I activities and were familiar with the research scope.

All experts were contacted via email and invited to take part in two-hour, face-to-face mini workshops with no more than two participants attending one session. In total, seven sessions were carried out. During the mini workshop, experts were introduced to the research background and the second version of the PSS+DM Design Tool. Later, they were allocated five Scenario Cards each, to ensure no cards remained unreviewed at the end of the study. In this way the Cards that received the most criticism from the participants of the first iteration were evaluated twice. The cards were allocated based on the expertise of the participants, e.g., cards containing scenarios describing 3D printing were allocated to the AM experts. Experts were given some time to get familiar with the contents of the Scenario Cards, and then they were asked to answer fifteen questions in order to evaluate completeness, effectiveness, and usability of the Scenario Cards and the Innovation Diagram. Although the study helped collect feedback from 10 knowledgeable experts, it had some limitations linked to time constrains and the diversity of experts' backgrounds within PSS and DM fields.

\subsubsection{Testing with Manufacturing Companies and Design Agencies}

Four manufacturing companies and two design agencies based in the South of Brazil were invited to apply the PSS+DM Design Tool in idea-generation workshops (Figure 8). The aim was to involve companies of various sizes from different industries with employees from different roles in order to comprehensively test the tool while having various expertise around the table during each workshop. Participants represented various roles including management, innovation, procurement, logistics and sales, combining expertise needed to design thorough PSS. Two of the participating companies were large international corporations producing vehicles and hydraulic systems. Another two companies were national medium-size cleaning equipment and food product manufacturers. The design agencies were specialising in product and service design. An open call of participation in the study was disseminated via email to all companies' and agencies' employees. In total, 91 participants took part in the testing of the design tool. All participating businesses were familiar with the Product-Service System concept and had ongoing PSS projects or PSS implementation in their near-future plans. In total, five, two-hour creativity sessions were carried out, one for each manufacturing company and a joined session for the design agencies. Each workshop started with an introductory presentation, providing an overview about PSS and DM and the Design Tool. Later, participants were split into groups and asked to apply the PSS+DM Design Tool to generate PSS ideas for their particular business context. Each creativity session ended with group presentations and a collective discussion. At the end of each session, participants were given questionnaires in order to evaluate the design tool's completeness, effectiveness, and usability. The study experienced some limitations related to participants' expertise and roles in companies, time constraints, and language barriers.

\subsubsection{Completeness}

Evaluation of completeness of the PSS+DM Design Tool aimed at evaluating the tool's contents, including PSS implementation barriers described on each Scenario Card, DM case studies, and the polarities of the Innovation Diagram. The majority of feedbacks provided by participants from companies and design agencies speaks positively about the contents of the Scenario Cards: "I can understand very well all explanations in scenario descriptions and the examples helped me to better understand." Experts helped identify those scenarios that required improved descriptions which directly address specific PSS implementation barriers presented on the Cards ("card 24-barrier is not related to the description"). Industry professionals from companies and design agencies identified limitations of DM case studies: "I think examples are focused in technologies industries, IT, mechanical, etc ... , but I didn't find examples that could be used in food companies." The axes of the Innovation Diagram were described as easy to comprehend, however, they can be supported with more explanations ("We understood as a 
sequence. Maybe you could put a legend on each box explaining better the propose.") (from companies and design agencies).
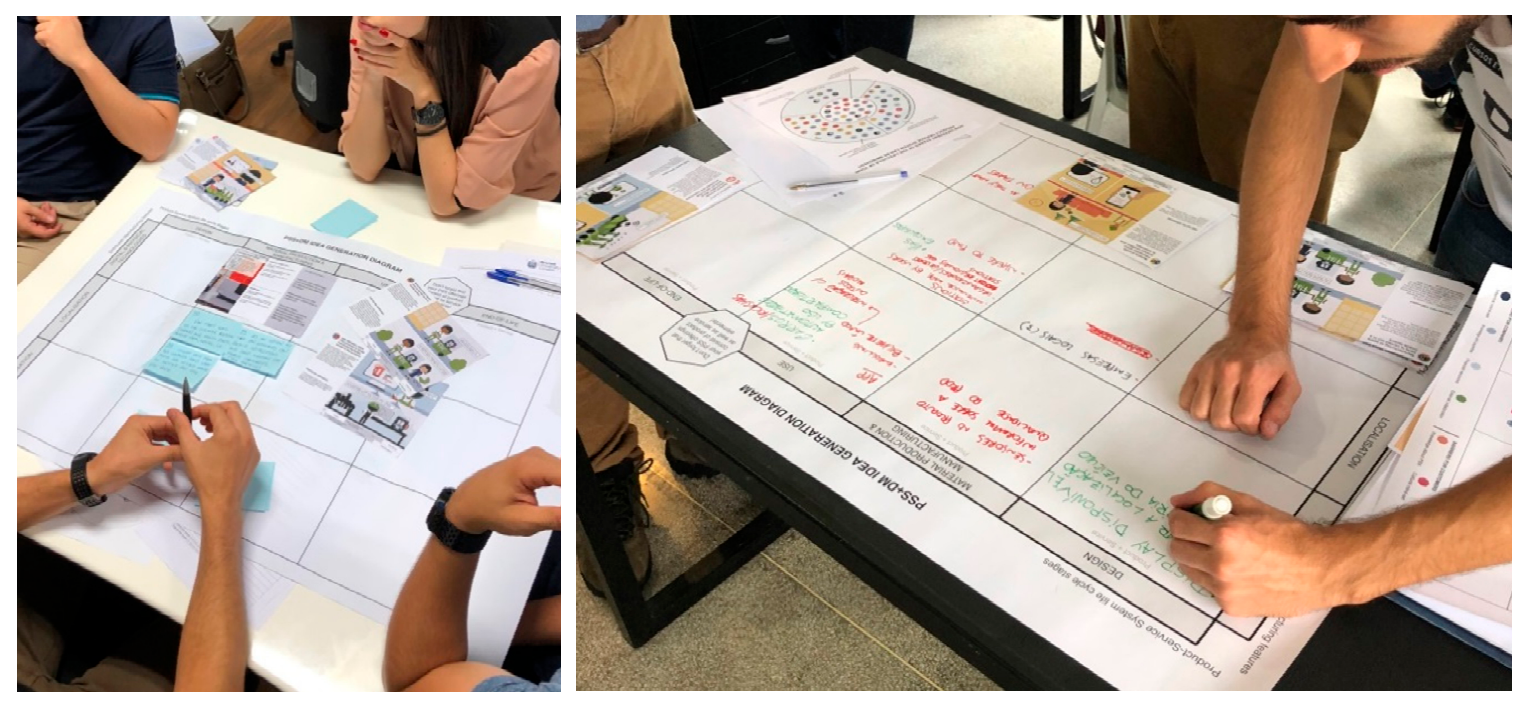

Figure 8. The design tool's testing with the manufacturing company (left) and the design agency.

\subsubsection{Effectiveness}

Evaluation of effectiveness of the Tool aimed at (1) showing understanding of potential benefits of DM application and (2) demonstrating how well the tool can support initial idea generation. The previous study with design students proved that the tool successfully supports PSS lifecycle-oriented thinking because of its architecture which encourages users to think in terms of lifecycle stages and generate ideas accordingly. For this reason, it was decided to not include the evaluation of this aspect in the second empirical testing, and rather use the limited time with experts to focus on other aspects of the tool.

The results of both studies show that the participants found that the Scenario Cards were able to effectively illustrate potential benefits of DM application: "Because of localisation element, DM element is very present" (from experts), "I definitely understood DM potential" (from companies and design agencies). Moreover, ideas developed by companies covered all three DM features. However, the tool's ability to support the idea generation process was identified as requiring further improvements: "More structured steps and clear guidelines are needed." (from experts).

\subsubsection{Usability}

Usability of the first version of the PSS+DM Design Tool aimed at assessing the layouts of the Scenario Cards and the Innovation Diagram. Participants of both studies expressed satisfaction about the layout of the cards ("very intuitive and easy to use" (from companies and design agencies)) and the diagram ("I like its simplicity, it makes it easy to understand" (from experts)). However, participants from companies and design agencies identified that Scenario Cards required a lot of reading ("I think the key information could be more highlighted"), and colours used in the Innovation Diagram caused issues ("The colours too similar one to another it confuses a little bit").

Summary of the results gained from questionnaires completed by companies and design agencies can be seen in Table 6 . The sample of experts was too small to be represented statistically and their feedback was not included in the table. Companies and design agencies gave higher evaluation points to all aspects of the Scenario Cards compared to the Innovation Diagram. Regarding the Innovation Diagram, companies identified the diagram as easy to use but gave the diagram's ability to support idea generation the lowest scores. However, the diagram's ability to support idea generation process is its secondary aim. The primary goal of the Diagram-i.e., to support lifecycle-oriented thinking-had 
already been successfully validated in the first testing and thus was not included in the second round of empirical testing. It can be summarised that the Scenario Cards and the Innovation Diagram partially achieved its design goals, however some minor changes need to be implemented.

Table 6. Feedback collected from companies and design agencies to evaluate completeness, effectiveness and usability of the PSS+DM Design Tool version 2.0.

\begin{tabular}{|c|c|c|c|c|c|c|c|}
\hline \multicolumn{8}{|c|}{ Scenario Cards } \\
\hline & \multirow{2}{*}{ Question } & \multicolumn{6}{|c|}{ Evaluation } \\
\hline & & $\begin{array}{l}1 \text { Very } \\
\text { Poor }\end{array}$ & $\begin{array}{c}2 \\
\text { Poor }\end{array}$ & $\begin{array}{c}3 \\
\text { Sufficient }\end{array}$ & $\begin{array}{c}4 \\
\text { Good }\end{array}$ & $\begin{array}{c}5 \\
\text { Excellent }\end{array}$ & Average \\
\hline 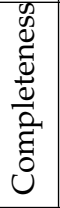 & $\begin{array}{l}\text { 1. To what extent are the contents } \\
\text { of the Scenario Cards sufficient? }\end{array}$ & $0 \%$ & $0 \%$ & $0 \%$ & $48 \%$ & $52 \%$ & 4.5 \\
\hline \multirow{2}{*}{ 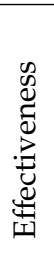 } & $\begin{array}{l}\text { 2. To what extent the Scenario } \\
\text { Cards helped you understand } \\
\text { potential benefits of DM applied to } \\
\text { PSS? }\end{array}$ & $0 \%$ & $0 \%$ & $9 \%$ & $43 \%$ & $48 \%$ & 4.4 \\
\hline & $\begin{array}{l}\text { 3. To what extent are the Scenario } \\
\text { Cards useful for idea generation } \\
\text { process? }\end{array}$ & $0 \%$ & $0 \%$ & $8 \%$ & $38 \%$ & $54 \%$ & 4.5 \\
\hline 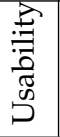 & $\begin{array}{l}\text { 4. To what extent are the Scenario } \\
\text { Cards easy to use? }\end{array}$ & $0 \%$ & $0 \%$ & $4 \%$ & $44 \%$ & $52 \%$ & 4.5 \\
\hline \multicolumn{8}{|c|}{ Innovation Diagram } \\
\hline & \multirow{2}{*}{ Question } & \multicolumn{6}{|c|}{ Evaluation } \\
\hline & & $\begin{array}{l}1 \text { Very } \\
\text { Poor }\end{array}$ & $\begin{array}{c}2 \\
\text { Poor }\end{array}$ & $\begin{array}{c}3 \\
\text { Sufficient }\end{array}$ & $\begin{array}{c}4 \\
\text { Good }\end{array}$ & $\begin{array}{c}5 \\
\text { Excellent }\end{array}$ & Average \\
\hline 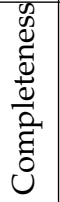 & $\begin{array}{l}\text { 1. To what extent are the contents } \\
\text { (axes) of the Idea Generation } \\
\text { Diagram sufficient? }\end{array}$ & $0 \%$ & $0 \%$ & $22 \%$ & $35 \%$ & $43 \%$ & 4.2 \\
\hline \multirow{2}{*}{ 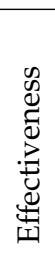 } & $\begin{array}{l}\text { 2. To what extent did the Idea } \\
\text { Generation Diagram help you } \\
\text { understand potential benefits of } \\
\text { DM applied to PSS? }\end{array}$ & $0 \%$ & $0 \%$ & $4 \%$ & $64 \%$ & $32 \%$ & 4.3 \\
\hline & $\begin{array}{l}\text { 3. To what extent is the Idea } \\
\text { Generation Diagram useful for the } \\
\text { idea generation process? }\end{array}$ & $0 \%$ & $0 \%$ & $18 \%$ & $50 \%$ & $32 \%$ & 4.1 \\
\hline 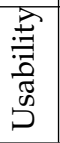 & $\begin{array}{l}\text { 4. To what extent is the Idea } \\
\text { Generation Diagram easy to use? }\end{array}$ & $0 \%$ & $0 \%$ & $18 \%$ & $41 \%$ & $41 \%$ & 4.2 \\
\hline
\end{tabular}

\subsection{Prescriptive Study III (PS-III): Development of the Final Version of the PSS+DM Design Tool}

Feedback collected during the empirical testing of the PSS+DM Design Tool version 2.0 has been analysed in order to identify the tool's strengths and weaknesses and to summarise potential improvements. By clustering this information, six recommendations for the final version of the PSS+DM Design Tool have been summarised. Table 7 presents the tool's advantages, disadvantages, and potential improvements. The following text describes new features of the Scenario Cards and the Innovation Diagram for the final version of the PSS+DM Design Tool. 
Table 7. Recommendations for new features for the final version of the PSS+DM Design Tool.

\begin{tabular}{|c|c|c|c|c|}
\hline \multicolumn{5}{|c|}{ Scenario Cards } \\
\hline & Worked & Did Not Work & $\begin{array}{l}\text { Examples of Suggestions } \\
\text { from Participants }\end{array}$ & $\begin{array}{l}\text { Recommendations } \\
\text { for New Features }\end{array}$ \\
\hline 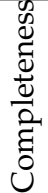 & \multirow{3}{*}{$\begin{array}{l}\text { 1. Illustrations } \\
\text { were identified as } \\
\text { clear, fun, and } \\
\text { engaging (from } \\
\text { experts). } \\
\text { 2. Scenarios were } \\
\text { easy to apply in the } \\
\text { specific business } \\
\text { context (from } \\
\text { companies). }\end{array}$} & $\begin{array}{l}\text { 1. DM case studies were } \\
\text { identified as difficult to } \\
\text { relate to. }\end{array}$ & $\begin{array}{l}\text { "I had difficulties because the } \\
\text { examples are very distant for } \\
\text { my work." (from companies } \\
\text { and design agencies) }\end{array}$ & $\begin{array}{l}\text { 1. Improve DM } \\
\text { case studies by } \\
\text { making them more } \\
\text { diverse. }\end{array}$ \\
\hline 总 & & $\begin{array}{l}\text { 2. Scenario illustrations } \\
\text { were identified as limiting } \\
\text { the idea generation } \\
\text { process. }\end{array}$ & $\begin{array}{l}\text { "Make images more } \\
\text { culturally diverse." (from } \\
\text { experts) }\end{array}$ & $\begin{array}{l}\text { 2. Make scenario } \\
\text { illustrations more } \\
\text { generic. }\end{array}$ \\
\hline 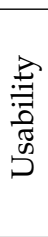 & & $\begin{array}{l}\text { 3. Analysis of the contents } \\
\text { of Scenario Cards required } \\
\text { more time than } \\
\text { participants expected } \\
\text { (from companies and } \\
\text { design agencies). }\end{array}$ & $\begin{array}{l}\text { "In my opinion, they could be } \\
\text { more direct and simple, with } \\
\text { less words and just } 1 \text { side." } \\
\text { (from companies and } \\
\text { design agencies) }\end{array}$ & $\begin{array}{l}\text { 3. Reduce, simplify } \\
\text { or better categorise } \\
\text { textual information, } \\
\text { including scenario } \\
\text { descriptions, PSS } \\
\text { barriers. }\end{array}$ \\
\hline \multicolumn{5}{|c|}{ Innovation Diagram } \\
\hline & Worked & Did Not Work & $\begin{array}{l}\text { Examples of Suggestions } \\
\text { from Participants }\end{array}$ & $\begin{array}{l}\text { Recommendations } \\
\text { for New Features }\end{array}$ \\
\hline 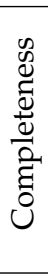 & \multirow{3}{*}{$\begin{array}{l}\text { 1. Scenario Cards } \\
\text { mapped on the } \\
\text { diagram provided } \\
\text { a good overall } \\
\text { picture of the } \\
\text { Design Tool (from } \\
\text { experts). } \\
\text { 2. Potential } \\
\text { applications of DM } \\
\text { features in each } \\
\text { PSS lifecycle stage } \\
\text { were well } \\
\text { understood (from } \\
\text { companies). }\end{array}$} & $\begin{array}{l}\text { 4. The Diagram was } \\
\text { identified as too } \\
\text { product-focused and not } \\
\text { efficient to support } \\
\text { PSS-oriented thinking } \\
\text { (from companies and } \\
\text { design agencies). }\end{array}$ & $\begin{array}{l}\text { "As we will use post-its, you } \\
\text { could put more information } \\
\text { inside the boxes." (from } \\
\text { companies and design } \\
\text { agencies) }\end{array}$ & $\begin{array}{l}\text { 4. Provide more } \\
\text { information about } \\
\text { PSS (questions or } \\
\text { suggestions) inside } \\
\text { empty squares of } \\
\text { the diagram. }\end{array}$ \\
\hline 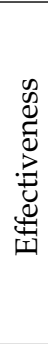 & & $\begin{array}{l}\text { 5. The Diagram was } \\
\text { missing clear guidelines } \\
\text { on how to use it (from } \\
\text { experts). }\end{array}$ & $\begin{array}{l}\text { "More guidelines for idea } \\
\text { navigation. Something that } \\
\text { shows idea inclination - if } \\
\text { user focuses on one corner of } \\
\text { the diagram, how to } \\
\text { encourage him/her to also } \\
\text { develop ideas in other areas? } \\
\text { Has the diagram to be } \\
\text { completed?" (from experts) }\end{array}$ & $\begin{array}{l}\text { 5. Provide more } \\
\text { guidelines on how } \\
\text { to select relevant } \\
\text { Scenario Cards and } \\
\text { use the Diagram. }\end{array}$ \\
\hline 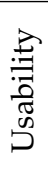 & & $\begin{array}{l}\text { 6. Colours were identified } \\
\text { as too similar and } \\
\text { confusing (from experts, } \\
\text { companies and design } \\
\text { agencies). }\end{array}$ & $\begin{array}{l}\text { "The colours are a problem. } \\
\text { Red is almost same as orange, } \\
\text { and the greys are close." } \\
\text { (from experts) }\end{array}$ & $\begin{array}{l}\text { 6. Improve colour } \\
\text { coding and } \\
\text { graphical } \\
\text { communication } \\
\text { elements. }\end{array}$ \\
\hline
\end{tabular}

Scenario Cards (Figure 9). First of all, the text on the front side of the card describing a scenario and PSS barriers was reduced where possible, making sure the core idea of each scenario was clearly and, at the same time, concisely presented. Secondly, each scenario illustration, provided on the front side of the Card, contains images of specific products (e.g., a kettle, a lamp, etc.). These images were required to be removed in order to make illustrations more generic and applicable by various industries. Finally, new DM case studies were selected to represent a broader range of examples in terms of company size and context.

Innovation Diagram (Figure 10). In order to facilitate the card selection process and encourage product- as well as service-oriented thinking, more textual information was placed in the diagram. This includes more information about each PSS lifecycle stage and questions triggering PSS-oriented idea generation in each section. More distinct colours representing mapped scenarios were chosen to avoid misunderstanding. 

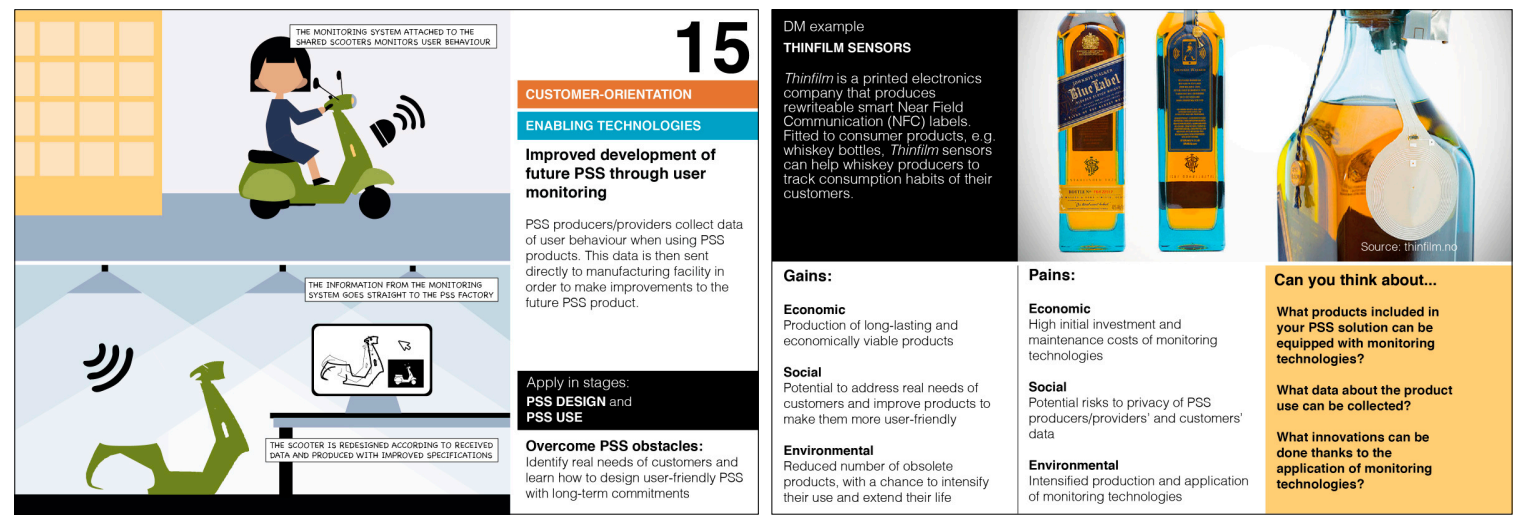

Figure 9. The front and back sides of one of the Scenario Cards (final version).

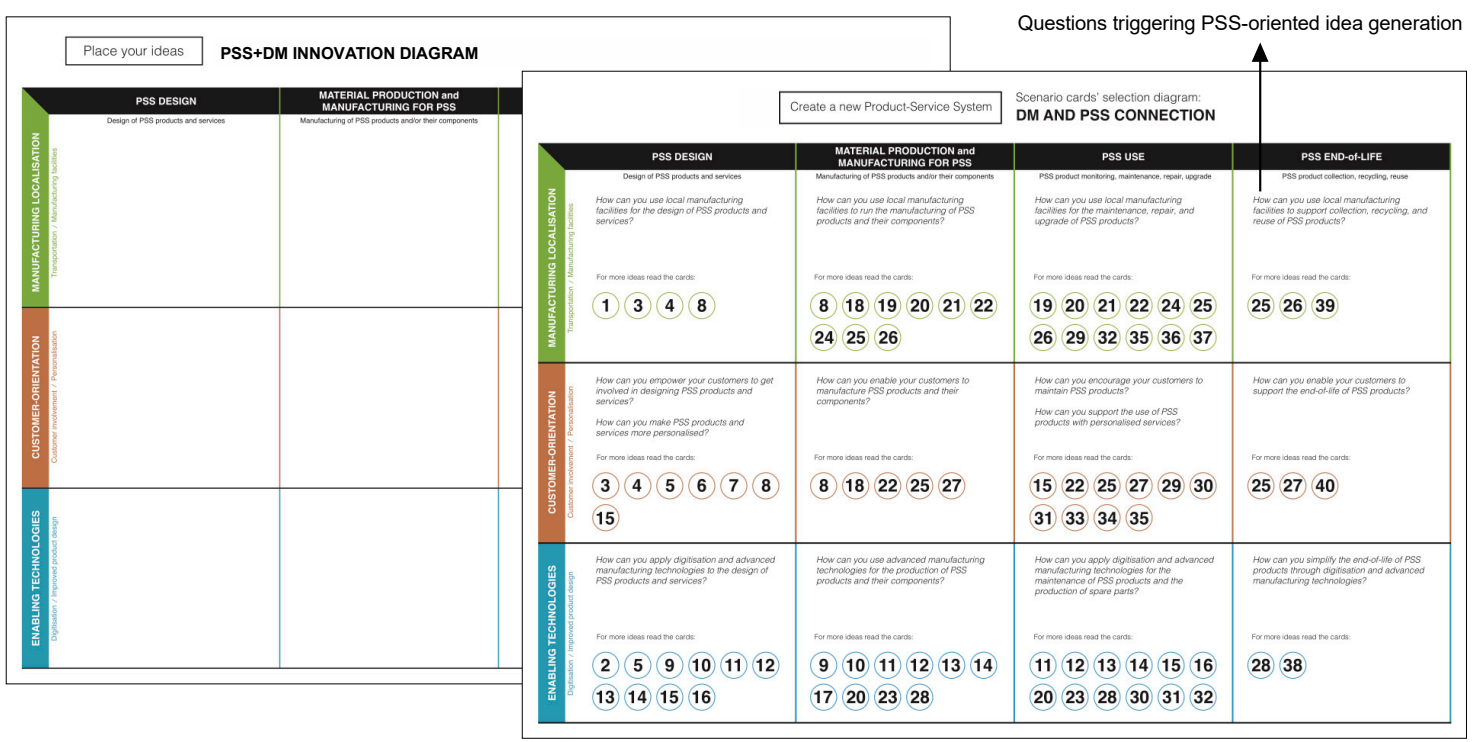

Figure 10. The final version of the PSS+DM Innovation Diagram.

\section{Conclusions and Future Research}

PSS implementation shows the potential to provide companies with competitive advantage, an ability to better satisfy the customer demand, and to improve business processes towards environmental, social, and economic sustainability. However, PSS implementation is still limited by a number of barriers linked to the mindset of organisational bodies, lack of customer acceptance, and absence of appropriate regulations. This paper described the research process which was carried out to develop the PSS+DM Design Tool, aiming to support the idea generation process for design of PSS offerings. Initial attempts to combine PSS and DM can be found in existing literature, however, a systematic analysis of how PSS barriers can be addressed by DM is still missing, making this research one-of-a-kind.

The first version of the PSS+DM Design Tool contained 35 near-future Scenario Cards which illustrated DM opportunities and their potential application to PSS implementation. All the Scenario Cards were classified and mapped on the Innovation Diagram made of two polarities representing key DM and PSS dimensions. One of the dimensions classifying the Scenario Cards along PSS lifecycle stages aims to encourage users to consider a complete PSS lifecycle and thus facilitate idea generation for sustainable PSS offerings. Scenarios, illustrated and presented on the Scenario Cards, were created by coupling existing PSS implementation barriers with near-future opportunities of DM. For this reason, they intended to address real-world obstacles of PSS implementation. The two rounds of empirical 
applications of the PSS+DM Design Tool, carried out with 45 students, 10 experts and 91 industry professionals, helped improve the initial version of the tool to better support the idea generation process for improved PSS implementation. The final version of the PSS+DM Design Tool comprises 40 near-future Scenario Cards, including diverse case studies and idea generation-supporting questions, and the Innovation Diagram, facilitating the Scenario Cards selection and application. Empirical tool applications with students, experts, companies, and design agencies proved that the tool can be applied by users from various industries and with different expertise and experiences.

The research presented in this paper contributes to both literature and industry. The contribution to literature is through the extensive collection of PSS implementation barriers, which have not been summarised in existing literature, and the collection of DM opportunities and challenges. The combination of PSS and DM, even though introduced in existing literature, is still under-researched, making PSS+DM near-future scenarios and the PSS+DM Design Tool novel and one-of-a-kind. The PSS+DM Design Tool, developed to support companies and design practitioners, makes the main contribution to industry. It was observed that the tool can be used by company staff at all levels and with different expertise, aiming to collaborate in generating initial ideas, detailing further aspects of a concept, and presenting a final PSS offering.

The research described in this paper partially answered the initial research question: How can we practically support the design of PSS offerings through the application of DM principles in order to address PSS implementation barriers? The tool has been tested multiple times with improvements made after each application, with the final version presented in this paper. However, like other design tools, especially those linked to rapidly evolving areas (e.g., technological development), the PSS+DM Design Tool can be further improved in the future. Future research could focus on detailing the tool for a specific industrial sector and updating it with the latest technological advances or as a result of new policies. Alternatively, the tool could be applied to support a company or a design agency to design a specific PSS offering from ideation to implementation, observing the entire design journey lasting several months. This type of a long-term observation was outside the scope of the LeNSin project and was not possible to accomplish within the timeframe of this research. Furthermore, the PSS+DM Design Tool can be included in the academic curriculum of educational institutions to support students in gaining knowledge about PSS implementation and DM features.

Author Contributions: Conceptualisation of the paper, A.P. and F.C.; methodology, A.P., F.C. and D.H.; data collection and analysis, A.P. and F.C.; writing —original draft preparation, A.P.; writing — review \& editing, F.C., D.H., E.P. and A.P.; visualisation, A.P.; supervision of A.P. PhD, F.C. (first supervisor), E.P. (second supervisor) and D.H. (research development advisor); project principal investigator, F.C.; project co-investigators, D.H. and E.P., funding acquisition, F.C. All authors have read and agreed to the published version of the manuscript.

Funding: The research was funded by the EU under the ERASMUS+ Programme (Project Number 561927-EPP-1-2015-1-IT-EPPKA2-CBHE-JP). The APC was funded by Brunel University London.

Acknowledgments: The research was part of the 'LeNSin, International Learning Network on Sustainability' project, 2015-2019.

Conflicts of Interest: The authors declare no conflict of interest. 


\section{Appendix A}

Table A1. A sample of PSS+DM near-future scenarios in accordance to PSS lifecycle stages.

\begin{tabular}{|c|c|c|c|}
\hline $\begin{array}{l}\text { Life Cycle } \\
\text { Stage }\end{array}$ & PSS+DM Near-Future Scenario & $\begin{array}{l}\text { Addressed PSS } \\
\text { Implementation } \\
\text { Barriers }\end{array}$ & $\begin{array}{l}\text { Applied DM } \\
\text { Opportunities }\end{array}$ \\
\hline PSS Design & $\begin{array}{l}\text { 2. Comparison between PSS and traditional } \\
\text { product-based solutions } \\
\text { PSS providers will supply sensors for customers } \\
\text { who are not yet sure whether they should choose } \\
\text { PSS offerings instead of purchased products. } \\
\text { Sensors will be applied to customers' products to } \\
\text { show energy consumption and lifecycle costs. Data } \\
\text { collected from sensors will be sent to PSS providers } \\
\text { in order to offer best suitable PSS solution as a } \\
\text { replacement of owned product. } \\
\text { Challenges: } \\
\text { - Fitting sensor technologies into existing } \\
\text { companies' processes, including high initial } \\
\text { investment, maintenance and upgrade; } \\
\text { - Encouraging customers to adopt monitoring } \\
\text { technology. }\end{array}$ & $\begin{array}{l}\text { 11. A lack of } \\
\text { knowledge and } \\
\text { practice in pricing } \\
\text { PSS offerings, } \\
\text { estimating cash flows } \\
\text { and financial savings. } \\
\text { 35. A lack of } \\
\text { information about } \\
\text { owned product } \\
\text { lifecycle costs and a } \\
\text { belief that service } \\
\text { "package" is more } \\
\text { expensive. }\end{array}$ & $\begin{array}{l}\text { 6. Improved product } \\
\text { monitoring through } \\
\text { the application of } \\
\text { sensor technology. }\end{array}$ \\
\hline $\begin{array}{c}\text { Material } \\
\text { Production } \\
\text { and } \\
\text { Manufacturing } \\
\text { for PSS }\end{array}$ & $\begin{array}{l}\text { 20. Remote control of manufacturing equipment } \\
\text { Digital files and data will be transferred around the } \\
\text { world in order to produce products in local } \\
\text { factories. Same digital standards and machinery } \\
\text { will provide an ability to control manufacturing } \\
\text { equipment from distance. } \\
\text { Challenges: } \\
\text { - Communication and information issues can make } \\
\text { manufacturing tasks difficult to manage. }\end{array}$ & $\begin{array}{l}\text { 16. Concerns linked } \\
\text { to sharing } \\
\text { knowledge, expertise, } \\
\text { and confidential } \\
\text { information about } \\
\text { internal procedures. }\end{array}$ & $\begin{array}{l}\text { 1. ICT-facilitated } \\
\text { collaboration between } \\
\text { geographically } \\
\text { dispersed stakeholders. } \\
\text { 3. Remote control of } \\
\text { manufacturing } \\
\text { equipment. }\end{array}$ \\
\hline Use of PSS & $\begin{array}{l}\text { 35. Maintenance of PSS products carried out by } \\
\text { customers at home } \\
\text { If something breaks down and a new spare part is } \\
\text { needed, customers will be able to find a digital } \\
\text { production file in an online library established by } \\
\text { the PSS provider. The spare part will be able to be } \\
\text { produced at the customer's home using personal } \\
\text { AM technologies. } \\
\text { Challenges: } \\
\text { - Company's privacy issues related to sharing } \\
\text { blueprints of products or product parts; } \\
\text { - Energy consumption of advanced technology. }\end{array}$ & $\begin{array}{l}\text { 21. \& } 39 \text {. Concerns of } \\
\text { the requirement for } \\
\text { PSS provider to } \\
\text { access customers' } \\
\text { personal data or even } \\
\text { enter into their } \\
\text { property. } \\
\text { 46. High labour } \\
\text { prices, which prevent } \\
\text { customers from } \\
\text { choosing } \\
\text { labour-intensive PSS } \\
\text { offerings. }\end{array}$ & $\begin{array}{l}\text { 24. Manufacturing in } \\
\text { real time at the point of } \\
\text { need. } \\
34 \text {. Improved } \\
\text { responsiveness, } \\
\text { flexibility and } \\
\text { efficiency for the } \\
\text { manufacturing of spare } \\
\text { parts. } \\
55 \text {. Facilitated } \\
\text { collaboration between } \\
\text { producer and } \\
\text { customer. }\end{array}$ \\
\hline $\begin{array}{c}\text { PSS } \\
\text { End-of-Life }\end{array}$ & $\begin{array}{l}\text { 38. Monitoring of PSS products for their } \\
\text { end-of-life } \\
\text { Products involved in PSS offerings will be } \\
\text { equipped with sensors and will be able to give a } \\
\text { feedback to PSS providers. PSS providers will be } \\
\text { informed when a product is obsolete or damaged } \\
\text { and requires to be collected. Monitoring will } \\
\text { enable PSS providers to ensure products are } \\
\text { collected at their end-of-life. } \\
\text { Challenges: } \\
\text { - High initial investment and maintenance costs } \\
\text { from PSS companies; } \\
\text { - Fitting new technologies into existing production } \\
\text { line; } \\
\text { - Maintaining operational transition towards sensor } \\
\text { implementation. }\end{array}$ & $\begin{array}{l}\text { 24. Challenges of } \\
\text { customers not being } \\
\text { willing to return the } \\
\text { product at the end of } \\
\text { contract. }\end{array}$ & $\begin{array}{l}\text { 6. Improved product } \\
\text { monitoring through } \\
\text { the application of } \\
\text { sensor technology. }\end{array}$ \\
\hline
\end{tabular}


Table A2. The list of PSS+DM near-future scenarios in accordance to PSS lifecycle stages.

\begin{tabular}{|c|c|c|c|}
\hline $\begin{array}{l}\text { PSS Life } \\
\text { Cycle } \\
\text { Stage }\end{array}$ & PSS+DM Near-Future Scenario & $\begin{array}{c}\text { Addressed PSS } \\
\text { Implementation } \\
\text { Barriers (From Table 2) }\end{array}$ & $\begin{array}{c}\text { Applied DM } \\
\text { Opportunities } \\
\text { (From Table 3) }\end{array}$ \\
\hline \multirow{16}{*}{ 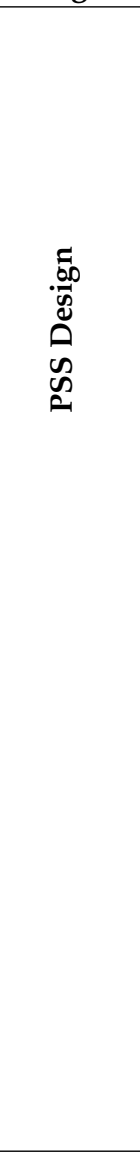 } & $\begin{array}{l}\text { 1. Facilitated implementation of PSS } \\
\text { businesses }\end{array}$ & 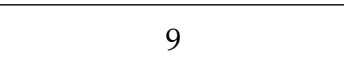 & 31,37 \\
\hline & $\begin{array}{l}\text { 2. Comparison between PSS and traditional } \\
\text { product-based solutions }\end{array}$ & 11,35 & 6 \\
\hline & $\begin{array}{l}\text { 3. PSS solutions created by customers in PSS } \\
\text { makerspaces }\end{array}$ & 20,38 & $24,26,29$ \\
\hline & $\begin{array}{l}\text { 4. Collaboration between PSS } \\
\text { producers/providers and customers in } \\
\text { makerspaces }\end{array}$ & 20,34 & $24,43,55$ \\
\hline & $\begin{array}{l}\text { 5. Customisation of existing PSS solutions } \\
\text { carried out by customers }\end{array}$ & 24 & 39,46 \\
\hline & $\begin{array}{l}\text { 6. Personalised PSS solutions designed by } \\
\text { customers themselves }\end{array}$ & 20,38 & $45,46,50$ \\
\hline & $\begin{array}{l}\text { 7. Entirely bespoke PSS solutions created for } \\
\text { each customer }\end{array}$ & 32 & 40,45 \\
\hline & 8. PSS solutions available on the high street & 20,31 & 27 \\
\hline & $\begin{array}{l}\text { 9. Reduced material usage enabled by } \\
\text { complex geometries of PSS products }\end{array}$ & 7,27 & 14 \\
\hline & $\begin{array}{l}\text { 10. Reduced number of materials needed to } \\
\text { produce PSS products }\end{array}$ & 7,27 & 14,16 \\
\hline & $\begin{array}{l}\text { 11. Design of self-(dis)assembling PSS } \\
\text { products }\end{array}$ & 27,29 & 18,19 \\
\hline & 12. Design of self-repairing PSS products & 23,42 & 18 \\
\hline & 13. Design of lightweight PSS products & 27 & 14,16 \\
\hline & $\begin{array}{l}\text { 14. Simplified components for } \\
\text { remanufacturing of PSS products }\end{array}$ & 27 & 16 \\
\hline & $\begin{array}{l}\text { 15. Improved development of future PSS } \\
\text { through the user monitoring }\end{array}$ & 5,7 & $6,7,11$ \\
\hline & $\begin{array}{l}\text { 16. Maintenance of PSS products predicted } \\
\text { through historical data }\end{array}$ & 25 & 6,9 \\
\hline \multirow{15}{*}{ 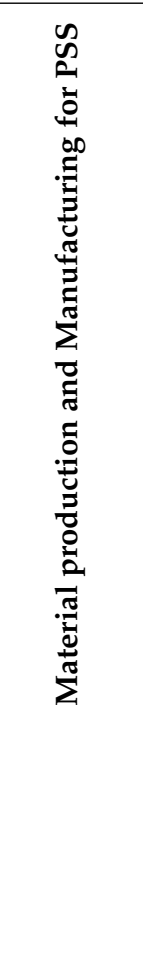 } & 8. PSS solutions available on the high street & 20,31 & 27 \\
\hline & $\begin{array}{l}\text { 9. Reduced material usage enabled by } \\
\text { complex geometries of PSS products }\end{array}$ & 7,27 & 14 \\
\hline & $\begin{array}{l}\text { 10. Reduced number of materials needed to } \\
\text { produce PSS products }\end{array}$ & 7,27 & 14,16 \\
\hline & $\begin{array}{l}\text { 11. Design of self-(dis)assembling PSS } \\
\text { products }\end{array}$ & 27,29 & 18,19 \\
\hline & 12. Design of self-repairing PSS products & 23,42 & 18 \\
\hline & 13. Design of lightweight PSS products & 27 & 14,16 \\
\hline & $\begin{array}{l}\text { 14. Simplified components for } \\
\text { remanufacturing of PSS products }\end{array}$ & 27 & 16 \\
\hline & 17. Reduced waste production & 27 & 14,40 \\
\hline & $\begin{array}{l}\text { 18. Home manufacturing of personalised } \\
\text { parts of PSS products }\end{array}$ & $36,39,42$ & $24,25,28$ \\
\hline & $\begin{array}{l}\text { 19. Outsourced manufacturing for localised } \\
\text { production of PSS solutions }\end{array}$ & 9,10 & $30,31,32$ \\
\hline & $\begin{array}{l}\text { 20. Remote control of manufacturing } \\
\text { equipment }\end{array}$ & 16 & 1,3 \\
\hline & $\begin{array}{l}\text { 21. Manufacturing kit for local production of } \\
\text { PSS solutions }\end{array}$ & 17,25 & 29,32 \\
\hline & $\begin{array}{l}\text { 22. Blueprints of PSS products available in } \\
\text { makerspaces }\end{array}$ & 42 & 33,47 \\
\hline & 23. Simplified upgrade of PSS products & 40 & 13,40 \\
\hline & $\begin{array}{l}\text { 24. Production and support of PSS solutions } \\
\text { carried out by local artisans }\end{array}$ & 6,25 & 36,39 \\
\hline
\end{tabular}


Table A2. Cont.

\begin{tabular}{|c|c|c|c|}
\hline $\begin{array}{l}\text { PSS Life } \\
\text { Cycle } \\
\text { Stage }\end{array}$ & PSS+DM Near-Future Scenario & $\begin{array}{c}\text { Addressed PSS } \\
\text { Implementation } \\
\text { Barriers (From Table 2) }\end{array}$ & $\begin{array}{l}\text { Applied DM } \\
\text { Opportunities } \\
\text { (From Table 3) }\end{array}$ \\
\hline \multirow{30}{*}{ 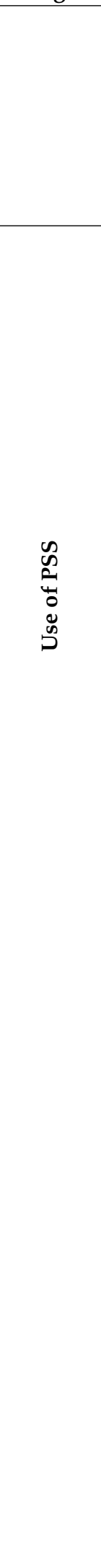 } & 25. Reduced number of supply chain actors & $16-19$ & $21,23,40$ \\
\hline & $\begin{array}{l}\text { 26. Simplified transportation through local } \\
\text { manufacturing }\end{array}$ & 29,40 & $21,22,23$ \\
\hline & $\begin{array}{l}\text { 27. Manufacturing ran by customers, service } \\
\text { provision carried out by PSS } \\
\text { producers/providers }\end{array}$ & 10 & 24,45 \\
\hline & $\begin{array}{l}\text { 28. Reverse engineering for remanufacturing } \\
\text { of components of PSS products }\end{array}$ & 25 & 13 \\
\hline & $\begin{array}{l}\text { 11. Design of self-(dis)assembling PSS } \\
\text { products }\end{array}$ & 27,29 & 18,19 \\
\hline & 12. Design of self-repairing PSS products & 23,42 & 18 \\
\hline & 13. Design of lightweight PSS products & 27 & 14,16 \\
\hline & $\begin{array}{l}\text { 14. Simplified components for } \\
\text { remanufacturing of PSS products }\end{array}$ & 27 & 16 \\
\hline & $\begin{array}{l}\text { 15. Improved development of future PSS } \\
\text { through the user monitoring }\end{array}$ & 5,7 & $6,7,11$ \\
\hline & $\begin{array}{l}\text { 16. Maintenance of PSS products predicted } \\
\text { through historical data }\end{array}$ & 25 & 6,9 \\
\hline & $\begin{array}{l}\text { 19. Outsourced manufacturing for localised } \\
\text { production of PSS solutions }\end{array}$ & 9,10 & $30,31,32$ \\
\hline & $\begin{array}{l}\text { 20. Remote control of manufacturing } \\
\text { equipment }\end{array}$ & 16 & 1,3 \\
\hline & $\begin{array}{l}\text { 21. Manufacturing kit for local production of } \\
\text { PSS solutions }\end{array}$ & 17,25 & 29,32 \\
\hline & $\begin{array}{l}\text { 22. Blueprints of PSS products available in } \\
\text { makerspaces }\end{array}$ & 42 & 33,47 \\
\hline & 23. Simplified upgrade of PSS products & 40 & 13,40 \\
\hline & $\begin{array}{l}\text { 24. Production and support of PSS solutions } \\
\text { carried out by local artisans }\end{array}$ & 6,25 & 36,39 \\
\hline & 25. Reduced number of supply chain actors & $16-19$ & $21,23,40$ \\
\hline & $\begin{array}{l}\text { 26. Simplified transportation through local } \\
\text { manufacturing }\end{array}$ & 29,40 & $21,22,23$ \\
\hline & $\begin{array}{l}\text { 27. Manufacturing ran by customers, service } \\
\text { provision carried out by PSS } \\
\text { producers/providers }\end{array}$ & 10 & 24,45 \\
\hline & $\begin{array}{l}\text { 28. Reverse engineering for remanufacturing } \\
\text { of components of PSS products }\end{array}$ & 25 & 13 \\
\hline & $\begin{array}{l}\text { 29. Educated customers with knowledge } \\
\text { about PSS benefits and maintenance }\end{array}$ & 34,36 & $48,49,50$ \\
\hline & $\begin{array}{l}\text { 30. Monitoring of PSS products carried out by } \\
\text { customers and PSS producers/providers }\end{array}$ & $23,26,40$ & 6,7 \\
\hline & $\begin{array}{l}\text { 31. Monitoring of hygiene of PSS products } \\
\text { carried out by customers }\end{array}$ & 41 & 6 \\
\hline & $\begin{array}{l}\text { 32. Identification of manufacturing facility } \\
\text { located closest to the customer }\end{array}$ & 25,40 & $1,2,21$ \\
\hline & $\begin{array}{l}\text { 33. Upgrade of PSS products with } \\
\text { personalised parts }\end{array}$ & 41 & $13,40,44$ \\
\hline & $\begin{array}{l}\text { 34. Home assemble and maintenance of PSS } \\
\text { products using a DIY kit }\end{array}$ & $25,29,39$ & 34 \\
\hline & $\begin{array}{l}\text { 35. Maintenance of PSS products carried out } \\
\text { by customers at home }\end{array}$ & $21,39,46$ & $24,34,55$ \\
\hline & $\begin{array}{l}\text { 36. Maintenance of PSS products carried out } \\
\text { by PSS producers/providers in makerspaces }\end{array}$ & 9,10 & 29,33 \\
\hline & $\begin{array}{l}\text { 37. Production of spare parts of PSS products } \\
\text { carried out in a mobile factory }\end{array}$ & $25,36,40,42$ & $23,24,25$ \\
\hline & $\begin{array}{l}\text { 38. Monitoring of PSS products for their } \\
\text { end-of-life }\end{array}$ & 24,26 & 6 \\
\hline
\end{tabular}


Table A2. Cont.

\begin{tabular}{|c|c|c|c|}
\hline $\begin{array}{l}\text { PSS Life } \\
\text { Cycle } \\
\text { Stage }\end{array}$ & PSS+DM Near-Future Scenario & $\begin{array}{c}\text { Addressed PSS } \\
\text { Implementation } \\
\text { Barriers (From Table 2) }\end{array}$ & $\begin{array}{c}\text { Applied DM } \\
\text { Opportunities } \\
\text { (From Table 3) }\end{array}$ \\
\hline \multirow{7}{*}{ 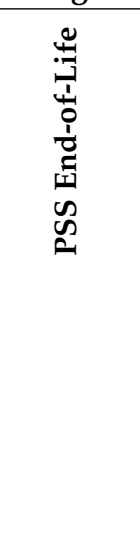 } & 25. Reduced number of supply chain actors & $16-19$ & $21,23,40$ \\
\hline & $\begin{array}{l}\text { 26. Simplified transportation through local } \\
\text { manufacturing }\end{array}$ & 29,40 & $21,22,23$ \\
\hline & $\begin{array}{l}\text { 27. Manufacturing ran by customers, service } \\
\text { provision carried out by PSS } \\
\text { producers/providers }\end{array}$ & 10 & 24,45 \\
\hline & $\begin{array}{l}\text { 28. Reverse engineering for remanufacturing } \\
\text { of components of PSS products }\end{array}$ & 25 & 13 \\
\hline & $\begin{array}{l}\text { 38. Monitoring of PSS products for their } \\
\text { end-of-life }\end{array}$ & 24 & 6 \\
\hline & $\begin{array}{l}\text { 39. Simplified collection of PSS products at } \\
\text { their end-of-life }\end{array}$ & 47 & $21,30,34$ \\
\hline & $\begin{array}{l}\text { 40. Transformation of obsolete PSS products } \\
\text { into personalised solutions }\end{array}$ & 24 & 40,51 \\
\hline
\end{tabular}

\section{References}

1. Tukker, A.; Tischner, U. New Business for Old Europe: Product-Service Development, Competitiveness and Sustainability; Greenleaf: Sheffield, UK, 2006.

2. Baines, T.S.; Lightfoot, H.W.; Evans, S.; Neely, A.D.; Greenough, R.; Peppard, J.; Roy, R.; Shehab, E.; Braganza, A.; Tiwari, A.; et al. State-of-the-art in product-service systems. Proc. Inst. Mech. Eng. Part B J. Eng. Manuf. 2007, 221, 1543-1552. [CrossRef]

3. Vasantha, G.V.A.; Roy, R.; Lelah, A.; Brissaud, D. A review of product-service systems design methodologies. J. Eng. Des. 2012, 23, 635-659. [CrossRef]

4. Cooper, T.; Evans, S. Products to Services. A Report for Friends of the Earth Produced by the Centre for Sustainable Consumption; Sheffield Hallam University: Sheffield, UK, 2000.

5. Mont, O. Clarifying the concept of product-service system. J. Clean. Prod. 2002, 10, 237-245. [CrossRef]

6. Besch, K. Product-service systems for office furniture: Barriers and opportunities on the European market. J. Clean. Prod. 2005, 13, 1083-1094. [CrossRef]

7. Sousa-Zomer, T.T.; Magalhães, L.; Zancul, E.; Cauchick-Miguel, P.A. Exploring the challenges for circular business implementation in manufacturing companies: An empirical investigation of a pay-per-use service provider. Resour. Conserv. Recycl. 2018, 135, 3-13. [CrossRef]

8. Ceschin, F. Critical factors for implementing and diffusing sustainable product-Service systems: Insights from innovation studies and companies' experiences. J. Clean. Prod. 2013, 45, 74-88. [CrossRef]

9. Ceschin, F. Sustainable Product-Service Systems; Springer Science and Business Media LLC: Berlin/Heidelberg, Germany, 2014.

10. Vezzoli, C.; Ceschin, F.; Diehl, J.C.; Kohtala, C. New design challenges to widely implement 'Sustainable Product-Service Systems'. J. Clean. Prod. 2015, 97, 1-12. [CrossRef]

11. Kohtala, C. Addressing sustainability in research on distributed production: An integrated literature review. J. Clean. Prod. 2015, 106, 654-668. [CrossRef]

12. Srai, J.S.; Kumar, M.; Graham, G.; Phillips, W.; Tooze, J.; Ford, S.; Beecher, P.; Raj, B.; Gregory, M.; Tiwari, M.K.; et al. Distributed manufacturing: Scope, challenges and opportunities. Int. J. Prod. Res. 2016, 54, 1-19. [CrossRef]

13. Petrulaityte, A.; Ceschin, F.; Eujin, P.; Harrison, D. Supporting Sustainable Product-Service System Implementation through Distributed Manufacturing. Procedia CIRP 2017, 64, 375-380. [CrossRef]

14. Suominen, J.; Piller, F.; Ruohonen, M.; Tseng, M.; Jacobson, S. Mass Matching-Customization, Configuration \& Creativity. In Proceedings of the 5th International Conference on Mass Customization \& Personalization MCPC 2009, Aalto University School of Art and Design Publication Series B 102, Helsinki, Finland, 4-8 October 2009. 
15. Reim, W.; Sjödin, D.R.; Parida, V. Adoption of Product-service System (PSS) Business Model Innovations in Global Distributer Networks. In Proceedings of the 24th International Product Development Management Conference IPDMC, Reykjavik, Iceland, 11-13 June 2017.

16. Miller, P.; O'Leary, T. Rethinking the Factory: Caterpillar Inc. Cult. Values 2002, 6, 91-117. [CrossRef]

17. Despeisse, M.; Ford, S. The Role of Additive Manufacturing in Improving Resource Efficiency and Sustainability. Advances in Production Management Systems: Innovative Production Management towards Sustainable Growth. In Proceedings of the International Conference, APMS 2015, Tokyo, Japan, 7-9 September 2015.

18. Moreno, M.; Charnley, F. Can Re-distributed Manufacturing and Digital Intelligence Enable a Regenerative Economy? An Integrative Literature Review. Hum. Centred Intell. Sys. 2016, 52, 563-575. [CrossRef]

19. Ford, S.; Despeisse, M. Additive manufacturing and sustainability: An exploratory study of the advantages and challenges. J. Clean. Prod. 2016, 137, 1573-1587. [CrossRef]

20. Moreno, M.; Turner, C.; Tiwari, A.; Hutabarat, W.; Charnley, F.; Widjaja, D.; Mondini, L. Re-distributed Manufacturing to Achieve a Circular Economy: A Case Study Utilizing IDEF0 Modeling. Procedia CIRP 2017, 63, 686-691. [CrossRef]

21. Charro, A.; Schaefer, D. Cloud Manufacturing as a new type of Product-Service System. Int. J. Comput. Integr. Manuf. 2018, 31, 1018-1033. [CrossRef]

22. Sinclair, M.; Sheldrick, L.; Moreno, M.; Dewberry, E. Consumer Intervention Mapping-A Tool for Designing Future Product Strategies within Circular Product Service Systems. Sustainability 2018, 10, 2088. [CrossRef]

23. Ingemarsdotter, E.; Jamsin, E.; Kortuem, G.; Balkenende, R. Circular Strategies Enabled by the Internet of Things-A Framework and Analysis of Current Practice. Sustainability 2019, 11, 5689. [CrossRef]

24. Haddad, Y.; Salonitis, K.; Emmanouilidis, C. Redistributed manufacturing of spare parts: An agent-based modelling approach. Procedia CIRP 2019, 81, 707-712. [CrossRef]

25. Ford, S.; Minshall, T. Defining the Research Agenda for 3D Printing-Enabled Re-distributed Manufacturing. In Proceedings of the Security Education and Critical Infrastructures; Springer Science and Business Media LLC: Berlin/Heidelberg, Germany, 2015; pp. 156-164.

26. Blessing, L.T.; Chakrabarti, A. DRM, a Design Research Methodology; Springer Science and Business Media LLC: Berlin/Heidelberg, Germany, 2009.

27. Meredith, J. Theory Building through Conceptual Methods. Int. J. Oper. Prod. Manag. 1993, 13, 3-11. [CrossRef]

28. Goodier, C.; Soetanto, R. Building future scenarios using cognitive mapping. J. Maps 2013, 9, $203-217$. [CrossRef]

29. Creswell, J.W. Qualitative Inquiry E Research Design: Choosing among Five Approaches, 3rd ed.; Sage: Thousand Oaks, CA, USA, 2013.

30. Creswell, J.W. Research Design; Sage Publications: London, UK, 2009.

31. Tukker, A. Eight types of product-service system: Eight ways to sustainability? Experiences from SusProNet. Bus. Strat. Environ. 2004, 13, 246-260. [CrossRef]

32. United Nations Environmental Programme (UNEP). Product-Service Systems and Sustainability. Opportunities for Sustainable Solutions; Division of Technology Industry and Economics, Production and Consumption Branch; UNEP: Paris, France, 2002.

33. Mont, O.; Lindhqvist, T. The role of public policy in advancement of product service systems. J. Clean. Prod. 2003, 11, 905-914. [CrossRef]

34. Ceschin, F. The Introduction and Scaling up of Sustainable Product-service Systems: A New Role for Strategic Design for Sustainability. Ph.D. Thesis, Politecnico di Milano, Milan, Italy, 2012.

35. Bartolomeo, M.; Maso, D.D.; De Jong, P.; Eder, P.; Groenewegen, P.; Hopkinson, P.G.; James, P.; Nijhuis, L.; Örninge, M.; Scholl, G.; et al. Eco-efficient producer services-What are they, how do they benefit customers and the environment and how likely are they to develop and be extensively utilised? J. Clean. Prod. 2003, 11, 829-837. [CrossRef]

36. Martínez, V.; Bastl, M.; Kingston, J.; Evans, S. Challenges in transforming manufacturing organisations into product-service providers. J. Manuf. Technol. Manag. 2010, 21, 449-469. [CrossRef]

37. Coreynen, W.; Matthyssens, P.; De Rijck, R.; Dewit, I. Internal levers for servitization: How product-oriented manufacturers can upscale product-service systems. Int. J. Prod. Res. 2017, 56, 2184-2198. [CrossRef] 
38. Mont, O. Drivers and barriers for shifting towards more service-oriented businesses: Analysis of the PSS field and contributions from Sweden. J. Sustain. Prod. Des. 2002, 2, 89-103. [CrossRef]

39. Matschewsky, J.; Kambanou, M.L.; Sakao, T. Designing and providing integrated product-service systems-Challenges, opportunities and solutions resulting from prescriptive approaches in two industrial companies. Int. J. Prod. Res. 2017, 56, 2150-2168. [CrossRef]

40. Barquet, A.P.B.; Oliveira, M.G.; Amigo, C.R.; Cunha, V.P.; Rozenfeld, H. Employing the business model concept to support the adoption of product-service systems (PPS). Ind. Mark. Manag. 2013, 42, 693-704. [CrossRef]

41. Mont, O. Product-Service Systems: Panacea or Myth? Ph.D. Thesis, Lund University, Lund, Sweden, 2004.

42. Catulli, M. What uncertainty? Further insight into why consumers might be distrustful of product service systems. J. Manuf. Tech. Manag. 2012, 23, 780-793. [CrossRef]

43. Rexfelt, O.; Ornäs, V.H.A. Consumer acceptance of product-service systems. J. Manuf. Technol. Manag. 2009, 20, 674-699. [CrossRef]

44. Manzini, E.; Vezzoli, C.; Clark, G. Product-Service Systems. Using an Existing Concept as a New Approach to Sustainability. J. Des. Res. 2001, 1. [CrossRef]

45. Edbring, E.G.; Lehner, M.; Mont, O. Exploring consumer attitudes to alternative models of consumption: Motivations and barriers. J. Clean. Prod. 2016, 123, 5-15. [CrossRef]

46. Ottosson, H. Personal Communication with Director of EnerSearch at Sydkraft; Mont, M.O., Ed.; Springer: New York, NY, USA, 2000.

47. Hannon, M.; Foxon, T.J.; Gale, W.F. 'Demand pull' government policies to support Product-Service System activity: The case of Energy Service Companies (ESCos) in the UK. J. Clean. Prod. 2015, 108, 900-915. [CrossRef]

48. Mont, O. Institutionalisation of sustainable consumption patterns based on shared use. Ecol. Econ. 2004, 50, 135-153. [CrossRef]

49. Armstrong, C.M.; Niinimäki, K.; Kujala, S.; Karell, E.; Lang, C. Sustainable product-service systems for clothing: Exploring consumer perceptions of consumption alternatives in Finland. J. Clean. Prod. 2015, 97, 30-39. [CrossRef]

50. Hobson, K.; Lynch, N.; Lilley, D.; Smalley, G.J. Systems of practice and the Circular Economy: Transforming mobile phone product service systems. Environ. Innov. Soc. Transit. 2018, 26, 147-157. [CrossRef]

51. Rizos, V.; Behrens, A.; Van der Gaast, W.; Hofman, E.; Ioannou, A.; Kafyeke, T.; Flamos, A.; Rinaldi, R.; Papadelis, S.; Hirschnitz-Garbers, M.; et al. Implementation of Circular Economy Business Models by Small and Medium-Sized Enterprises (SMEs): Barriers and Enablers. Sustainability 2016, 8, 1212. [CrossRef]

52. Kuo, T.-C.; Ma, H.-Y.; Huang, S.H.; Hu, A.H.; Huang, C.S. Barrier analysis for product service system using interpretive structural model. Int. J. Adv. Manuf. Technol. 2009, 49, 407-417. [CrossRef]

53. Wallin, J.; Parida, V.; Isaksson, O. Understanding product-service system innovation capabilities development for manufacturing companies. J. Manuf. Technol. Manag. 2015, 26, 763-787. [CrossRef]

54. Linder, M.; Williander, M. Circular Business Model Innovation: Inherent Uncertainties. Bus. Strat. Environ. 2015, 26, 182-196. [CrossRef]

55. Mont, O. Product-Service Systems; International Institute of Industrial Environmental Economics, Lund University: Lund, Sweden, 2000.

56. Wong, M. Implementation of Innovative Product Service-Systems in the Consumer Goods Industry. Ph.D. Thesis, Cambridge University, Cambridge, UK, 2004.

57. Mont, O. Introducing and Developing a Product-Service System (PSS) Concept in Sweden; IIIEE Reports 2001:6. Lund: IIIEE; Lund University and NUTEK: Lund, Sweden, 2001.

58. Cherry, C.; Pidgeon, N. Why Is Ownership an Issue? Exploring Factors That Determine Public Acceptance of Product-Service Systems. Sustainability 2018, 10, 2289. [CrossRef]

59. Oliva, R.; Kallenberg, R. Managing the transition from products to services. Int. J. Serv. Ind. Manag. 2003, 14, 160-172. [CrossRef]

60. Mont, O.; Dalhammar, C.; Jacobsson, N. A new business model for baby prams based on leasing and product remanufacturing. J. Clean. Prod. 2006, 14, 1509-1518. [CrossRef]

61. Catulli, M.; Cook, M.; Potter, S. Mapping transitions towards sustainable consumption: Latitudes, legends and declinations in the interaction between consumers culture and sustainable business models. Paper presented at Consumer Culture Theory Conference-CCT 2014, Helsinki, Finland, 26-29 June 2014. 
62. Sakao, T.; Rönnbäck, A.O.; Sandström, G.O. Uncovering benefits and risks of integrated product service offerings-Using a case of technology encapsulation. J. Sys. Sci. Sys. Eng. 2013, 22, 421-439. [CrossRef]

63. Bardhi, F.; Eckhardt, G.M. Access-Based Consumption: The Case of Car Sharing: Table 1. J. Consum. Res. 2012, 39, 881-898. [CrossRef]

64. Enckell, C.; Isgran, M. Barriers towards a successful adoption of PSS: A Provider and Customer Perspective. Master's Thesis, Lulea University of Technology, Lulea, Sweden, 2017.

65. Bessière, D.; Charnley, F.; Tiwari, A.; Moreno, M. A vision of re-distributed manufacturing for the UK's consumer goods industry. Prod. Plan. Control. 2019, 30, 555-567. [CrossRef]

66. Kumar, M.; Tsolakis, N.; Agarwal, A.; Srai, J.S. Developing distributed manufacturing strategies from the perspective of a product-process matrix. Int. J. Prod. Econ. 2020, 219, 1-17. [CrossRef]

67. Rauch, E.; Dallinger, M.; Dallasega, P.; Matt, D.T. Sustainability in Manufacturing through Distributed Manufacturing Systems (DMS). Procedia CIRP 2015, 29, 544-549. [CrossRef]

68. Pearson, H.; Noble, G.; Hawkins, J. Re-Distributed Manufacturing Workshop Report; EPSRC: Swindon, UK, 2013.

69. Matt, D.T.; Rauch, E.; Dallasega, P. Trends towards Distributed Manufacturing Systems and Modern Forms for their Design. Procedia CIRP 2015, 33, 185-190. [CrossRef]

70. Kühnle, H. Distributed Manufacturing (DM)—Smart Units and Collaborative Processes. Int. J. Soc. Behav. Educ. Econ. Bus. Ind. Eng. 2015, 9.

71. Basmer, S.; Buxbaum-Conradi, S.; Krenz, P.; Redlich, T.; Wulfsberg, J.; Bruhns, F.-L. Open Production: Chances for Social Sustainability in Manufacturing. Procedia CIRP 2015, 26, 46-51. [CrossRef]

72. Christian Lerch Competence Center for Sustainability and Infrastructure Systems at the Fraunhofer Institute for Systems and Innovation Research ISI Karlsruhe Germany Digitalized Product-Service Systems in Manufacturing Firms: A Case Study Analysis. Res. Manag. 2015, 58, 45-52. [CrossRef]

73. Mitchell, A.; Lafont, U.; Hołyńska, M.; Semprimoschnig, C. Additive manufacturing-A review of 4D printing and future applications. Addit. Manuf. 2018, 24, 606-626. [CrossRef]

74. Eujin, P.; Loh, G.H.; Harrison, D.L.; Almeida, H.; Verona, M.D.M.; Paz, R. A study of 4D printing and functionally graded additive manufacturing. Assem. Autom. 2017, 37, 147-153. [CrossRef]

75. Durão, L.F.C.S.; Christ, A.; Zancul, E.; Anderl, R.; Schützer, K. Additive manufacturing scenarios for distributed production of spare parts. Int. J. Adv. Manuf. Technol. 2017, 93, 869-880. [CrossRef]

76. Eujin, P.; Ressin, M.; Campbell, I.; Eynard, B.; Xiao, J. Investigating the impact of additive manufacturing data exchange standards for re-distributed manufacturing. Prog. Addit. Manuf. 2019, 4, 331-344. [CrossRef]

77. Liu, H.; Purvis, L.; Mason, R.; Wells, P. Developing logistics value propositions: Drawing Insights from a distributed manufacturing solution. Ind. Mark. Manag. 2020. [CrossRef]

78. Foresight. The Future of Manufacturing: A New Era of Opportunity and Challenge for the UK; Project Report The Government Office for Science: London, UK, 2013.

79. Ellwein, C.; Schmidt, A.; Lechler, A.; Riedel, O. Distributed Manufacturing; Association for Computing Machinery (ACM): New York, NY, USA, 2019; pp. 90-95.

80. Bonvoisin, J.; Galla, J.K.; Prendeville, S. Design Principles for Do-It-Yourself Production. In Human Centred Intelligent Systems; Springer Science and Business Media LLC: Berlin/Heidelberg, Germany, 2017; pp. 77-86.

81. Ardolino, M.; Rapaccini, M.; Saccani, N.; Gaiardelli, P.; Crespi, G.; Ruggeri, C. The role of digital technologies for the service transformation of industrial companies. Int. J. Prod. Res. 2017, 56, 2116-2132. [CrossRef]

82. Freitas, D.; Almeida, H.; Bartolo, H.; Bártolo, P.J. Sustainability in extrusion-based additive manufacturing technologies. Prog. Addit. Manuf. 2016, 1, 65-78. [CrossRef]

83. Gyires, T.; Muthuswamy, B. A planning algorithm for distributed manufacturing. In Proceedings International Conference on Intelligent and Cooperative Information Systems; Institute of Electrical and Electronics Engineers (IEEE): Piscataway, NJ, USA, 2002; pp. 237-246.

84. Bogers, M.; Hadar, R.; Bilberg, A. Additive manufacturing for consumer-centric business models: Implications for supply chains in consumer goods manufacturing. Technol. Forecast. Soc. Chang. 2016, 102, 225-239. [CrossRef]

85. Nagarajan, H.P.N.; Raman, A.S.; Haapala, K.R. A Sustainability Assessment Framework for Dynamic Cloud-based Distributed Manufacturing. Procedia CIRP 2018, 69, 136-141. [CrossRef]

86. Angeles-Martinez, L.; Theodoropoulos, C.; Lopez-Quiroga, E.; Fryer, P.; Bakalis, S. The Honeycomb model: A platform for systematic analysis of different manufacturing scenarios for fast-moving consumer goods. J. Clean. Prod. 2018, 193, 315-326. [CrossRef] 
87. Lelah, A.; Boucher, X.; Moreau, V.; Zwolinski, P. Product-Service Systems Scenarios as a Tool for Transition towards Sustainable PSS'. Product Services Systems and Value Creation. In Proceedings of the 6th CIRP Conference on Industrial, IPSS 2014, Windsor, ON, Canada, 1-2 May 2014.

88. Aurich, J.C.; Schweitzer, E.; Fuchs, C. Life Cycle Management of Industrial Product-Service Systems; Springer Science and Business Media LLC: Berlin/Heidelberg, Germany, 2007; pp. 171-176.

89. Chiu, F.-C. Fit between future thinking and future orientation on creative imagination. Think. Ski. Creat. 2012, 7, 234-244. [CrossRef]

90. Corubolo, M.; Jégou, F.; Meroni, A.; Piredda, F.; Zhang, Z. Visual Material Presenting Emerging Best Practices and Emerging Visions on Sustainable Lifestyles; The emerging visions. Part 2; Deliverable for SPREAD Sustainable Lifestyles; Politecnico di Milano: Milan, Italy, 2011.

91. Eames, M.; Hunt, M.; Dixon, T.; Britnell, J. Retrofit City Futures: Visions for Urban Sustainability; Report for the Retrofit 2050, Cardiff University: Cardiff, UK, 2013.

92. Forum for the Future. Fashion Futures 2025: Global Scenarios for a Sustainable Fashion Industry; Forum for the Future and Levi Strauss: London, UK, 2010.

93. Forum for the Future. Consumer Futures 2020; Scenarios for tomorrow's consumer; Forum for the Future and Sainsbury's and Unilever: London, UK, 2011.

94. Government Office for Science. Tackling Obesities: Future Choices_Visualising the Future: Scenarios to 2050; Department of Innovation Universities and Skills: London, UK, 2007.

95. Jégou, F.; Seyrig, A.; Scholl, G. Sustainable Street 2030: CORPUS Toolkit for Collaborative Scenario Building; Institut für ökologische Wirtschaftsforschung GmbH: Berlin, Germany, 2013.

96. Ryan, C.; Twomey, P.; Gaziulusoy, A.I.; McGrail, S.; Chandler, P. Scenarios 2040-Results from the Second Year of Visions and Pathways 2040; Scenarios of Low Carbon Living: Melbourne, Australia, 2016.

97. Taylor, R.; Frame, B.; Delaney, K.; Brignall-Theyer, M. 4 Future Scenarios for New Zealand; Manaaki Whenua Press: Lincoln, New Zealand, 2007.

98. Virdis, M.R. Energy to 2050: Scenarios for a Sustainable Future; OECD/IEA: Paris, France, 2003.

99. Manzini, E.; Jégou, F. The Construction of Design-Orienting Scenarios; Final report; SusHouse Project; Faculty of Technology, Policy and Management, Delft University of Technology: Amsterdam, The Netherlands, 2000.

100. Emili, S.; Ceschin, F.; Harrison, D. Product-Service Systems applied to Distributed Renewable Energy: A classification system and 15 archetypal models. Energy Sustain. Dev. 2016, 32, 71-98. [CrossRef] 